\title{
Development and Validation of a Global Competency Framework for Preparing New Graduates for Early Career Professional Roles
}

Mark H. Strong, MS

Strong Talent Strategies, Bellaire, Texas, United States

Gary J. Burkholder, PhD

Walden University, Minneapolis, Minnesota, United States

(iD https://orcid.org/0000-0002-5084-8099

Emily G. Solberg, $\mathrm{PhD}$

SHL, Palatine, Illinois, United States

Amy Stellmack, $\mathrm{PhD}$

Korn Ferry, Minneapolis, Minnesota, United States

William D. Presson, $\mathrm{PhD}$

City of Houston, Houston, Texas, United States

Jean-Bernard Seitz, MBA

Ed4Skills, Arnold, Maryland, United States

Contact: mark.strong@strongtalentstrategies.com

\section{Abstract}

Objectives: The current objectives include the development of a global competency model applicable across a wide range of jobs, industries, and geographies for university graduates entering the workplace.

Method: The competency model was developed utilizing a global panel of subject matter experts and a validation survey of over 25,000 students, faculty, staff, and employers across more than 30 countries.

Results: The results showed substantial consistency for the importance and criticality ratings of the competencies, with Achieving Objectives, Analyzing and Solving Problems, Adapting to Change, Communicating Orally, Learning and Self-Development, Making Decisions, Planning and Organizing, and Working Well with Others as the highest-rated competencies across regions, roles, and industries.

Conclusions: The most important competencies for students entering the workforce were consistent across different jobs, different industries, and different countries. The diversity and varied experience levels of the sample provide greater generalizability than most competency modeling projects that are often idiosyncratic to specific roles, industries, subjects, or levels. 
Implication for Theory and/or Practice: University faculty and staff can use the results of the validation study to develop curricula and programs that will be better able to foster important competencies to ensure that their students are better prepared to enter the workplace. Although some organizations emphasize leadership as important for all professional employees, Managing the Work of Others, Leading Others, and Influencing Others were consistently rated lower in importance by employers across all roles and regions and may not be appropriate as the primary focus of skill development for new graduates.

Keywords: competency model; work-readiness; survey

Submitted: August 3, 2020 | Accepted: October 20, 2020 | Published: December 1, 2020 Recommended Citation

Strong, M., Burkholder, G. J., Solberg, E. G., Stellmack, A., Presson, W. D., \& Seitz, J.-B. (2020). Development and validation of a global competency framework for preparing new graduates for early career professional roles. Higher Learning Research Communications, 10, 67-115. https://doi.org/10.18870/hlrc.v10i2.1205

\section{Introduction}

Academic programs have received a rapidly increasing call to incorporate skills that have been referred to as soft skills and, most recently, 21st-century skills. Merisotis and Hauser (2020) noted that significant changes to higher education as a result of COVID-19 provide an opportunity to refocus the way we think about the goals of higher education: "While we're spending billions to save higher education, college and university leaders should focus on engaging today's students. They will have to focus more clearly on building people's skills for work and civic life [italics by the current authors], including coming up with better approaches for them to demonstrate what they know and can do" (p. 1). This is not only a United States phenomenon. Mobility across borders requires that students be prepared for jobs in the global market, and competency mapping is becoming increasingly popular with employers when seeking candidates (Bhagra \& Sharma, 2018). In an examination of employer expectations, Karzunina et al. (2018) found that, for all but one of the 15 employability skills identified, employers reported a distinct difference between the importance of the skill and new hire preparation in that skill and that this difference was noted generally across regions and countries.

Many universities are finding ways to incorporate essential employability skills into their curriculum (Schaffhauser, 2020), particularly as competency-based programs are becoming more popular. Integration is not necessarily straightforward, as there needs to be clear identification of which skills are important, the specific competencies required, and the integration into curricular development efforts and effective assessment (Care et al., 2018). In addition, agencies are emerging, among them the Quality Assurance Commons (https://theqacommons.org/), that certify programs which adequately prepare students for the workplace. The messages from higher education and the workplace are clear: We need to do a better job of preparing graduates for a dynamic workplace.

Our goal was to develop a comprehensive, global competency-model framework for a large network of international institutions of higher education grounded in the current needs of global employers. The model needed to be relevant across cultural contexts, disciplines, and languages. Such a competency framework would allow each of the institutions to incorporate specific competencies into the curriculum and then to assess and improve the work readiness of its students before they graduate and enter the professional workforce. Additionally, results of assessment data based on the framework could be used to modify the curriculum to ensure that student learning outcomes match the needs of employers. 


\section{Literature Review of Competency Modeling}

Competency modeling has been most clearly defined by Campion et al. (2011) as "collections of knowledge, skills, abilities, and other characteristics (KSAOs) that are needed for effective performance in the jobs in question" (p. 226). The purpose of competency models can be wide ranging, but most organizations use them to serve as the foundation for talent management activities that can impact all levels of an organization (Sanchez \& Levine, 2009). An estimated 70\% to 80\% of Fortune 500 companies use some type of competency model (Stone et al., 2013). Competency models can help inform a wide variety of organizational practices and initiatives, such as employee selection, career development, leadership development, and organizational change (Stevens, 2012).

Although competency modeling is commonly used in the world of work, it is also becoming more prevalent in areas outside of the traditional work environment (Stevens, 2012), such as in educational settings. For example, competency models are beginning to be used in academic training programs. Paulson (2001) argued that postsecondary institutions should be training students in the skills and abilities that enhance competencies related to liberal arts education and necessary for workplace success. Competency models have served as the foundation for competency-based education that ensures graduates have the necessary knowledge and skills to practice in their professions in many disciplines, including the health sciences (Mirzazadeh et al., 2013) and STEM fields (Jang, 2016). Given the growing emphasis on preparing college graduates for the professional workforce, it is critical to understand the competencies that employers seek in new graduates so they can be embedded into academic curricula and other development programs for students. Thus, understanding the competencies deemed important and critical by global employers is crucial for developing a comprehensive academic curriculum that prepares students for the world of work.

Several researchers have attempted to develop a core set of competencies that would apply in any organization (Prahalad \& Hamel, 1990; Bartram, 2005). Core competencies are designed as components of an organization's strategy as opposed to a set of individual attributes (Prahalad \& Hamel, 1990). This idea was advanced by Lawler (1994), who wrote that identification of job-related knowledge, skills, abilities, and other characteristics (KSAO) should not be driven by job analysis at a single job level, but on a set of competencies derived via an organizational analysis.

\section{Competency Modeling Frameworks in Higher Education}

By understanding the ways that employers use competency model frameworks, higher education institutions can use this information to develop frameworks that map to the curriculum and help enhance students' skill development (Lucia \& Lepsinger, 1999; Schippmann et al., 2000; Zemke, 1982). Paulson (2001) wrote, "it seems obvious that educators can no longer rely on mere convening of classes and granting of diplomas as sufficient proof that their graduates meet workplace needs" (p. 42). She goes on to write, "employers increasingly view diplomas and degrees with skepticism and want different measures to use when recruiting and retraining employees. Competencies can offer a suitable alternative" (p. 42).

Higher education has shown tremendous growth in the development of competency model frameworks. These frameworks match curricular requirements to employer or discipline needs. For example, Mirzazadeh et al. (2014) used a participatory approach with faculty and students to develop a competency framework comprising eight domains of academic and practice skills required for work in the health professions (clinical skills; communication skills; patient management; health promotion and disease prevention; personal development; professionalism; medical ethics; and law) (p. 710). Other published competency models generated to assess preparation for the workplace include University of Kansas Master of Public Administration students (Getha-Taylor et al., 2013); Master's in Human Resource Development for students in Korea (Lee 2009); and New Zealand graduate business school students (Hodges \& Burchell, 2003). Lunev 
et al. (2013) have also created a competency model to be used across a variety of disciplines; however, their work focused specifically on Russian industry.

Thus, studies demonstrate that competency model frameworks are a useful means to ensure students are prepared for the workplace. Most frameworks have been designed to apply to specific disciplinary, institutional, and programmatic contexts. However, few studies have provided examples of competency model frameworks that are developed at the outset to be global in nature, meaning that they apply across a broad cross-section of industries, cultural contexts, and languages. In a workforce that is becoming increasingly global, training students to be successful globally potentially provides them with a competitive advantage when seeking work.

\section{Competency Model Best Practices}

We followed the recommendations from a Society for Industrial and Organizational Psychology (SIOP) taskforce, which identified several essential elements for competency model development (Campion, et al., 2011). First, the competency model was linked to cross-industry organizational goals and objectives by gathering input from over 5,000 professionals working in organizations around the world during the development and validation of the competency model; thus, the competency model is connected with the needs of employers and addresses a key focus area involving academic-employer relationships. Second, the development of the competency model framework was driven by senior management and established as a priority for Laureate Education, Inc., a global network of institutions of higher education. To ensure buy-in, we assembled a global panel of stakeholders from across the organization to act as reviewers of all work processes and outputs. Third, we conducted dozens of focus groups using job analysis techniques with employers, faculty/staff, and students from around the world that included discussions of the work performed by new graduates and the knowledge, skills, abilities, and other characteristics needed to perform the work. Fourth, each competency was developed with a clear behavioral definition as well as detailed descriptions of what performance looks like at different levels of proficiency. The result of these best practices is a library of 20 competencies that apply to a variety of degrees across fields of study and across the widest range of earlycareer professional jobs.

\section{Purpose of the Study}

The development of the competency modeling framework is part of an ambitious, multi-year project that began in 2015 to identify, define, and measure the foundational competencies and behavioral skills graduating students require to be successful in entry-level professional jobs across industries and geographic regions. Ultimately, students are assessed on their attainment of knowledge and skills-related workplace competencies prior to graduation. The framework was developed to serve as the basis for education initiatives that seek to improve program curricula and student development at institutions across the Laureate International network. The specific objectives of this project were to (1) develop a behavioral competency framework/library, involving the input of multiple stakeholders including global employers, that would serve as the basis for other competency-based education initiatives; (2) define the competencies required by graduating students to be successful in the global workplace, enhance their employability, and lead to sustained professional success; and (3) ensure applicability of the model across all campuses, geographic regions, and fields of study. 


\section{Methods}

\section{Context}

This competency model was developed by Laureate Education, Inc., a global network of institutions of higher education; at the time of development, Laureate was operating in 25 countries that included over one million students worldwide. As part of their mission, Laureate's network institutions deliver professional-oriented programs across a broad range of disciplines. These disciplines encompass the health sciences; social sciences and education; engineering; business; hospitality and culinary; and art and design, among others. It also had at the time over 50,000 faculty members; many of those faculty also work in their professions and bring a unique perspective to the classroom. Given its size, breadth of programs, and institutions across the globe, Laureate Education was extremely well positioned to undertake the development of a global competency model framework based on input from employers, faculty, staff, students, and alumni that would address the needs of its global student body and the employers with whom they will work after graduation.

\section{Procedure}

\section{Review}

Initial development of the framework began by reviewing existing competency models in the competency and education research literature, reviewing internal models that had been developed independently by several institutions in the Laureate network, and compiling existing competency research and data gathered by SHL, a talent management organization that helps companies attract, develop, and grow the workforce they need to succeed, over time across a variety of organizations. This initial review was conducted to understand the current state of research in competency models, their application in educational and employment settings, and to ensure buy-in from multiple internal Laureate stakeholders interested in workplace competency development. The primary focus of the review was identifying more general competencies that are relevant globally and across job roles (e.g., working with others, problem solving) rather than competencies that are more narrow or job specific (e.g., mechanical aptitude, programming capability).

\section{Drafting the competencies and competency-related behaviors}

Once the relevant competency research and data were compiled, competency information was combined into a competency crosswalk spreadsheet listing all of the competencies identified in the literature as well as a count of how many sources each competency was found in to help identify trends, overlap, and gaps in the various models. Industrial-organizational psychologist subject matter experts reviewed the document and distilled 21 initial competencies for which titles, definitions, and proficiency levels were drafted. Some of the themes that emerged from the literature review were the importance of adaptability, resilience, continuous learning, and problem solving. Some competencies were less prevalent (e.g., social responsibility, technology) in the literature review but were included in the initial model as they were apparently becoming more critical in the current work environment and likely will continue to grow in importance.

The team of I/O psychologists then drafted behaviors that exemplified each competency. For each behavior, the team drafted descriptions of the three levels of proficiency-foundational, intermediate, and advanced. Foundational was written to reflect the level generally expected of students when they are ready to enter the workforce as entry-level professionals. The initial drafts were thoroughly reviewed in an iterative process involving the I/O psychologists and the Laureate project team.

\section{Global stakeholder focus groups}

Draft competencies were reviewed, revised, and ultimately approved by a global advisory council of Laureate leaders. Following approval by the advisory council, the project team conducted 18 global focus groups (comprised of 100 people total) with employers of university graduates and academic leaders, faculty, staff, alumni, and students. The primary objective of the focus groups was to gather information from diverse 
stakeholders by facilitating discussions about the competencies, behaviors, and proficiency-level descriptions. Most focus groups were conducted in English, as English is the language of business for the Laureate network. However, four of the focus groups were conducted in Spanish. All Laureate network regions were well represented in the focus groups.

\section{Focus group feedback review}

Following the focus groups, we organized all feedback by type of participant, region, competency, behavior, and proficiency level. Project leaders experienced in competency model development reviewed and made decisions about how to incorporate each piece of feedback. Additional project team members were brought in to reconcile disagreement or conflicting feedback as needed. After several revisions to the competency model based on the results of the focus groups, the advisory council reconvened for further review of the model. Additionally, the model was presented to 10 regional senior academic and business leaders for final approval in a series of four steering committee meetings, one for each of the four Laureate network regions. The resulting competency model contained 20 competencies that reflect the broad capabilities and behaviors required across jobs and professions, private sector and public sector roles, large and small businesses, and a wide range of industries. Appendix A contains the competencies and associated behaviors.

\section{Competency validation survey}

The purpose of the validation survey was to collect data on perceived importance of the competencies and associated behaviors. We also wanted to ensure, as part of a Laureate network buy-in campaign, that a representative group of employers and experts across Laureate institutions, geographic regions/cultures, and fields of study evaluated the model. We included students, many of whom work part or full time, as well as alumni who are already in the workplace, to ensure that we had a student view of the framework. Surveys were translated and launched in 12 languages: Arabic, Bahasa Malaysia, Brazilian Portuguese, English, French, German, Greek, Latin American Spanish, Malaysian Simplified Chinese, Spanish, Thai, and Turkish.

Participants were asked for each competency, "how important is this competency for the successful performance of new professionals entering the workplace?” They then assigned a rating based on a 5-point scale ( 1 = Not At All Important; 2 = Somewhat Important; 3 = Important; 4 = Very Important; 5 = Critically Important). In addition to rating the importance of each competency, participants were asked to choose the competencies that they deemed most critical. Specifically, respondents were shown all 20 competencies and asked to select at least five and no more than 10 competencies that they believed to be the most critical for new professionals.

\section{Sample}

The sampling plan called for participation from 17,577 participants across all roles of interest, including current students, faculty, staff/administrators, alumni, and employers. A total of 30,146 individuals entered the survey, some of whom dropped out before answering any questions. The final sample in the analysis dataset included 25,202 participants, exceeding the original sampling plan by 7,625 individuals (43\%). More than 5,000 professionals and employers from around the world that were not currently affiliated with the university chose to participate. The professionals and employers were solicited through the university's alumni and other professional networks. Individuals from different levels within employing organizations participated in the survey, including approximately equal percentages of respondents falling into individual contributor, first-line supervisors, mid-level managers, senior managers, and other categories. These individuals provide first-hand perspective on the capabilities expected of new professionals entering the workplace. The survey data were examined to ensure that only high-quality data were retained for analysis. Participants were excluded based on two criteria, 1) if they completed the survey in less than two and a half minutes, or 2) if they had a standard deviation of zero in all responses. 


\section{Results}

Analysis of the survey data focused on: (a) evaluating the importance of each competency across geographic regions, (b) evaluating the importance of each competency by industry, and (c) evaluating the importance ratings of each competency by role (i.e., students, faculty, administrators, alumni, and employers). Given the importance of information from participants within potential employing organizations (e.g., supervisors, hiring managers, HR professionals) regarding the expectations of entry-level professionals, many of the subsequent analyses focus on this "employer" data. The results, however, are generally consistent across students, faculty/staff, administrators, and alumni roles.

Appendix A provides definitions for each of the 20 competencies validated in the study. Table 1 shows the overall $M, S D$, inter-rater agreement $\left(r w_{g}\right)$ and rank of the Importance rating for each competency across all respondents and for the Employer role. Rank is the numerical order of the importance means, with $1=$ most important and 20 = least important. When two competencies had the same mean to the hundredth decimal place value (.01), the same rank was given so as not to exaggerate minor differences in means. Inter-rater agreement was calculated using the $r w_{g}$ statistic (Burke \& Dunlap, 2002). This index varies between 0 and 1 and is used to assess agreement when multiple raters rate a single item. It compares the observed standard deviation in ratings to the expected standard deviation if the ratings were random (James et al., 1984). That is, the $r w_{g}$ describes the extent to which individuals agree on the rating of an item compared to the agreement that would be expected by chance. A $r w_{g}$ of 1 indicates perfect agreement and $r w_{g}$ of o indicates complete lack of agreement. At the overall level, the $r w_{g}$ ranged from .55 to .69 , indicating moderate to high levels of agreement. All competencies received a mean importance rating of at least 3.0 (with the lowest rating being 3.8), indicating that they are all validated as being important for entry-level professionals.

\section{Consistency Across Roles, Regions, and Industries}

There was remarkable consistency in the importance ratings of the competencies across regions, industries, and roles. The following competencies were rated as very important (mean rating greater than 4.0) across all regions, industries, and roles: (a) Achieving Objectives; (b) Analyzing and Solving Problems; (c) Adapting to Change; (d) Communicating Orally; (e) Learning and Self-Development; (f) Making Decisions; (g) Planning and Organizing; and (h) Working Well with Others. Competencies with a rating of at least 3.o but less than 4.0 include: (a) Applying a Global Mindset; (b) Exhibiting Resilience; (c) Influencing Others; (d) Cultivating a Strategic and Entrepreneurial Mindset; and (e) Managing the Work of Others.

The rank ordering of competencies was very consistent across participant roles, with the highest-rated and lowest-rated competencies generally the same across groups (see Table 2). One notable exception is that faculty, staff, and administrators rated Upholding Ethical Standards and Social Responsibility in the top three competencies while students, alumni, and employers had rankings for that competency in the middle range 
Table 1: Competency Ratings by Employers and Overall

\begin{tabular}{|c|c|c|c|c|c|c|c|c|c|c|}
\hline \multirow[b]{2}{*}{ Competency } & \multicolumn{5}{|c|}{ Employer } & \multicolumn{5}{|c|}{ Overall } \\
\hline & $\mathrm{N}$ & M & SD & $\mathrm{Rw}_{\mathrm{g}}$ & Rank & $\mathrm{N}$ & M & SD & $\mathrm{Rw}_{\mathrm{g}}$ & Rank \\
\hline 1. Achieving Objectives & 5101 & 4.20 & .797 & .68 & 7 & 25000 & 4.22 & .799 & .68 & 10 \\
\hline 2. Adapting to Change & 5101 & 4.24 & .757 & .71 & 5 & 24999 & 4.23 & .783 & .69 & 9 \\
\hline 3. Analyzing \& Solving Problems & 5101 & 4.28 & .781 & .70 & 3 & 25000 & 4.32 & .785 & .69 & 3 \\
\hline 4. Applying a Global Mindset & 5101 & 3.73 & .953 & .55 & 18 & 25000 & 3.88 & .924 & .57 & 18 \\
\hline 5. Communicating in Writing & 5101 & 4.04 & .860 & .63 & 12 & 25000 & 4.07 & .880 & .61 & 13 \\
\hline 6. Communicating Orally & 5101 & 4.29 & .772 & .70 & 2 & 25000 & 4.33 & .790 & .69 & 1 \\
\hline $\begin{array}{l}\text { 7. Cultivating a Strategic \& Entrepreneurial } \\
\text { Mindset }\end{array}$ & 5101 & 3.84 & .923 & .57 & 17 & 24999 & 3.92 & .910 & .59 & 17 \\
\hline 8. Demonstrating Accountability & 5101 & 4.24 & .831 & .65 & 5 & 25000 & 4.29 & .826 & .66 & 5 \\
\hline 9. Exhibiting Resilience & 5101 & 3.93 & .856 & 63 & 15 & 25000 & 3.98 & .858 & .63 & 16 \\
\hline 10. Generating Ideas \& Innovating & 5101 & 4.02 & .858 & .63 & 13 & 25000 & 4.13 & .851 & .64 & 12 \\
\hline 11. Influencing Others & 5089 & 3.73 & .923 & .57 & 18 & 24910 & 3.84 & .901 & .59 & 19 \\
\hline 12. Leading Others & 5089 & 3.89 & .979 & .52 & 16 & 24910 & 3.99 & .925 & .57 & 15 \\
\hline 13. Learning \& Self-Development & 5089 & 4.26 & .790 & 69 & 4 & 24910 & $4 \cdot 3$ & .791 & .69 & 4 \\
\hline 14. Leveraging Technology & 5089 & 3.97 & .871 & .62 & 14 & 24910 & 4.06 & .863 & .63 & 14 \\
\hline 15. Making Decisions & 5089 & 4.13 & .863 & .63 & 11 & 24910 & 4.24 & .826 & .66 & 7 \\
\hline 16. Managing the Work of Others & 5089 & 3.69 & 1.023 & .48 & 20 & 24910 & 3.8 & .949 & .55 & 20 \\
\hline 17. Meeting Customer/Stakeholder Expectations & 5089 & 4.17 & .864 & .63 & 9 & 24910 & 4.14 & .877 & .62 & 11 \\
\hline 18. Planning \& Organizing & 5089 & 4.17 & .827 & .66 & 9 & 24910 & 4.24 & .814 & 67 & 7 \\
\hline $\begin{array}{l}\text { 19. Upholding Ethical Standards \& Demonstrating } \\
\text { Social Responsibility }\end{array}$ & 5089 & 4.18 & .872 & 62 & 8 & 24910 & 4.25 & .856 & .63 & 6 \\
\hline 20. Working Well With Others & 5089 & 4.30 & .787 & .69 & 1 & 24910 & 4.33 & .791 & .69 & 1 \\
\hline
\end{tabular}

Note. Ninety participants only completed the first 10 ratings (Students $\mathrm{N}=60$; Faculty/Staff $\mathrm{N}=6$; Administrator $\mathrm{N}=3 ; \mathrm{Alumni} \mathrm{N}=9$; Employer $\mathrm{N}=12$ ); ${ }^{*}$ student participants answered only 19 ratings. 
Table 2: Competency Ratings by Laureate Role and Overall

\begin{tabular}{|c|c|c|c|c|c|c|}
\hline & Overall & Student & $\begin{array}{c}\text { Faculty/ } \\
\text { Staff }\end{array}$ & Administrator & Alumni & Employer \\
\hline Competency Components & Rank & Rank & Rank & Rank & Rank & Rank \\
\hline Communicating Orally & 1 & 2 & 3 & 4 & 1 & 2 \\
\hline Working Well With Others & 1 & 1 & 3 & 2 & 3 & 1 \\
\hline Analyzing \& Solving Problems & 3 & 4 & 1 & 1 & 2 & 3 \\
\hline Learning \& Self-Development & 4 & 3 & 5 & 6 & 5 & 4 \\
\hline Demonstrating Accountability & 5 & 5 & 5 & 9 & 3 & 5 \\
\hline Upholding Ethical Standards \& Demonstrating Social Responsibility & 6 & 8 & 1 & 3 & 10 & 8 \\
\hline Making Decisions & 7 & 6 & 8 & 6 & 6 & 11 \\
\hline Planning \& Organizing & 7 & 7 & 8 & 6 & 6 & 9 \\
\hline Adapting to Change & 9 & 11 & 5 & 5 & 8 & 5 \\
\hline Achieving Objectives & 10 & 9 & 8 & 10 & 8 & 7 \\
\hline Meeting Customer/Stakeholder Expectations & 11 & 12 & 14 & 11 & 11 & 9 \\
\hline Generating Ideas \& Innovating & 12 & 10 & 12 & 12 & 13 & 13 \\
\hline Communicating in Writing & 13 & 15 & 11 & 13 & 14 & 12 \\
\hline Leveraging Technology & 14 & 13 & 13 & 14 & 12 & 14 \\
\hline Leading Others & 15 & 14 & 16 & 15 & 16 & 16 \\
\hline Exhibiting Resilience & 16 & 17 & 15 & 16 & 15 & 15 \\
\hline Cultivating a Strategic \& Entrepreneurial Mindset & 17 & 16 & 18 & 17 & 17 & 17 \\
\hline Applying a Global Mindset & 18 & 18 & 17 & 20 & 18 & 18 \\
\hline Influencing Others & 19 & 19 & 19 & 19 & 19 & 18 \\
\hline Managing the Work of Others & 20 & 20 & 19 & 18 & 20 & 20 \\
\hline
\end{tabular}

Note. Sample Sizes (Overall N = 24,910 - 25,000; Student N = 10,0613 - 10,0673; Faculty/Staff N = 5,820 - 5,826; Administrator N =

1,443 - 1,446; Alumni $N=1,945$ - 1,954; Employer $N=5,089$-5,101) 
The competency rankings by industry are shown in Table 4, and they similarly display high levels of consistency. Working Well With Others rated in the top three most important competencies by six of the eight industry sectors, and Communicating Orally and Analyzing and Solving Problems were both rated in the top three most important competencies for five of the eight industry sectors. As it was by region, Managing the Work of Others was consistently ranked as one of the least important competencies across industries. Applying a Global Mindset was also ranked among the least important competencies. Some notable differences across industries were that Generating Ideas and Innovating was ranked most highly by respondents from the creative industries, and Upholding Ethical Standards was particularly highly ranked in the healthcare and government industries. 
Table 3: Competency Ratings by Region

\begin{tabular}{|c|c|c|c|c|c|c|c|}
\hline & Overall & Africa & $\begin{array}{l}\text { Americas- } \\
\text { Canada/US }\end{array}$ & $\begin{array}{c}\text { Americas- } \\
\text { Latin } \\
\text { America }\end{array}$ & Asia & Europe & Oceania \\
\hline Competency Components & Rank & Rank & Rank & Rank & Rank & Rank & Rank \\
\hline Communicating Orally & 1 & 5 & 5 & 2 & 3 & 2 & 2 \\
\hline Working Well With Others & 1 & 1 & 2 & 3 & 2 & 2 & 1 \\
\hline Analyzing \& Solving Problems & 3 & 9 & 4 & 1 & 4 & 2 & 6 \\
\hline Learning \& Self-Development & 4 & 3 & 7 & 6 & 1 & 1 & 5 \\
\hline Demonstrating Accountability & 5 & 8 & 3 & 4 & 9 & 5 & 7 \\
\hline $\begin{array}{l}\text { Upholding Ethical Standards \& Demonstrating } \\
\text { Social Responsibility }\end{array}$ & 6 & 1 & 1 & 7 & 7 & 11 & 3 \\
\hline Making Decisions & 7 & 12 & 10 & 5 & 12 & 9 & 12 \\
\hline Planning \& Organizing & 7 & 9 & 12 & 7 & 6 & 7 & 7 \\
\hline Adapting to Change & 9 & 5 & 5 & 10 & 4 & 6 & 4 \\
\hline Achieving Objectives & 10 & 5 & 8 & 9 & 8 & 8 & 10 \\
\hline Meeting Customer/Stakeholder Expectations & 11 & 4 & 13 & 12 & 9 & 10 & 9 \\
\hline Generating Ideas \& Innovating & 12 & 13 & 14 & 11 & 11 & 11 & 14 \\
\hline Communicating in Writing & 13 & 11 & 8 & 15 & 14 & 13 & 13 \\
\hline Leveraging Technology & 14 & 15 & 14 & 13 & 15 & 16 & 14 \\
\hline Leading Others & 15 & 17 & 16 & 14 & 17 & 18 & 16 \\
\hline Exhibiting Resilience & 16 & 13 & 10 & 17 & 13 & 14 & 11 \\
\hline Cultivating a Strategic \& Entrepreneurial Mindset & 17 & 16 & 19 & 16 & 17 & 15 & 19 \\
\hline Applying a Global Mindset & 18 & 18 & 18 & 18 & 16 & 17 & 17 \\
\hline Influencing Others & 19 & 19 & 17 & 19 & 19 & 19 & 17 \\
\hline Managing the Work of Others & 20 & 20 & 20 & 20 & 20 & 20 & 20 \\
\hline
\end{tabular}

Note. Sample Sizes (Overall N = 24,910; Africa N = 862; Americas US/Canada N = 1,520; Americas Latin America N = 17,205; Asia N = 2,135; Europe $\mathrm{N}=2,808$; Oceania $\mathrm{N}=326$ ) 
Table 4: Competency Ratings by Industry

\begin{tabular}{|c|c|c|c|c|c|c|c|c|}
\hline Competency Components & $\begin{array}{c}\text { Overall } \\
\text { Rank }\end{array}$ & $\begin{array}{c}\text { Manufacturing } \\
\text { Rank }\end{array}$ & $\begin{array}{c}\text { Professional } \\
\text { Services } \\
\text { Rank }\end{array}$ & $\begin{array}{c}\text { Consumer } \\
\text { Services } \\
\text { Rank }\end{array}$ & $\begin{array}{c}\text { Creative } \\
\text { Industries } \\
\text { Rank }\end{array}$ & $\begin{array}{l}\text { Health } \\
\text { care } \\
\text { Rank }\end{array}$ & $\begin{array}{c}\text { Government } \\
\text { Non-Profit } \\
\text { Rank }\end{array}$ & $\begin{array}{c}\text { Banking } \\
\text { Finance } \\
\text { Rank }\end{array}$ \\
\hline Communicating Orally & 1 & 6 & 1 & 2 & 2 & 4 & 4 & 1 \\
\hline Working Well With Others & 1 & 4 & 5 & 1 & 3 & 2 & 1 & 1 \\
\hline Analyzing \& Solving Problems & 3 & 1 & 1 & 6 & 1 & 3 & 3 & 4 \\
\hline Learning \& Self-Development & 4 & 2 & 4 & 3 & 4 & 5 & 6 & 5 \\
\hline Demonstrating Accountability & 5 & 2 & 3 & 4 & 8 & 6 & 5 & 1 \\
\hline $\begin{array}{l}\text { Upholding Ethical Standards \& } \\
\text { Demonstrating Social Responsibility }\end{array}$ & 6 & 11 & 7 & 10 & 10 & 1 & 2 & 9 \\
\hline Making Decisions & 7 & 9 & 10 & 10 & 10 & 8 & 8 & 11 \\
\hline Planning \& Organizing & 7 & 8 & 9 & 7 & 6 & 10 & 8 & 10 \\
\hline Adapting to Change & 9 & 6 & 5 & 4 & 6 & 7 & 6 & 6 \\
\hline Achieving Objectives & 10 & 4 & 8 & 7 & 8 & 9 & 8 & 7 \\
\hline $\begin{array}{l}\text { Meeting Customer/Stakeholder } \\
\text { Expectations }\end{array}$ & 11 & 9 & 11 & 9 & 13 & 12 & 14 & 7 \\
\hline Generating Ideas \& Innovating & 12 & 12 & 13 & 12 & 5 & 14 & 12 & 14 \\
\hline Communicating in Writing & 13 & 14 & 12 & 13 & 12 & 11 & 11 & 13 \\
\hline Leveraging Technology & 14 & 13 & 14 & 16 & 14 & 15 & 13 & 12 \\
\hline Leading Others & 15 & 15 & 15 & 15 & 17 & 16 & 16 & 17 \\
\hline Exhibiting Resilience & 16 & 16 & 17 & 14 & 15 & 13 & 15 & 16 \\
\hline $\begin{array}{l}\text { Cultivating a Strategic \& } \\
\text { Entrepreneurial Mindset }\end{array}$ & 17 & 17 & 16 & 17 & 18 & 20 & 17 & 15 \\
\hline Applying a Global Mindset & 18 & 18 & 18 & 18 & 16 & 18 & 19 & 18 \\
\hline Influencing Others & 19 & 19 & 19 & 19 & 19 & 17 & 18 & 19 \\
\hline Managing the Work of Others & 20 & 20 & 20 & 20 & 20 & 19 & 20 & 20 \\
\hline
\end{tabular}

Note. Participants indicated if they were currently working in a professional role; Faculty/Staff and Administrators were asked about currently working in an industry outside of their university work role. Sample sizes (Overall N = 24,910; Manufacturing N = 2,776;

Professional Services N = 2,735; Consumer Services N = 1,829; Creative Industries N = 1,094; Healthcare N = 1,277; Government, Non-Profit $\mathrm{N}=1,432$; Banking \& Finance $\mathrm{N}=638$ ) 


\section{Identification of the Most Critical Competencies}

For the identification of the most critical competencies, Table 5 shows the number of competencies chosen by participants, with over $40 \%$ of participants choosing 10 competencies as critical. Table 6 shows the percentage of individuals who identified each competency as critical, as well as the rankings by role. Rank is the numerical order of the percentages, with 1 indicating that the competency was identified as critical by the highest percentage of individuals and 20 indicating that it was identified as critical by the lowest percentage of individuals. When the same percentage of individuals chose two competencies, the same rank was given so as not to exaggerate minor differences. As was found with the importance ratings, there is considerable consistency in the criticality rankings across roles.

Significant overlap exists between the top 10 competencies identified by importance and the top 10 identified by criticality. One competency, Generating Ideas \& Innovating, was included in the 10 most important competencies but not the 10 competencies most frequently identified as critical. Another competency, Upholding Ethical Standards \& Demonstrating Social Responsibility, was one of the top 10 competencies in terms of criticality but not importance. Otherwise all of the competencies were the same in both ranking lists, demonstrating a great deal of consistency in the rating tasks. Given the similarity in the results across role groups and the focus on data from employers, Figure 1 provides a visual representation of the importance and criticality of the competencies for the employer data.

Table 5: Number of Competencies Chosen as Critical by Participants

\begin{tabular}{cc}
$\begin{array}{c}\text { Number of Competencies } \\
\text { Selected as Critical }\end{array}$ & $\mathrm{N}$ \\
\hline 5 & 4032 \\
6 & 2369 \\
7 & 2801 \\
8 & 2787 \\
9 & 2589 \\
10 & 10178 \\
Overall & $\mathbf{2 4 7 5 6}$
\end{tabular}

Note. 446 participants had full or partial competency rating data but no criticality ratings 
Table 6: Competency Ratings by Laureate Role and Overall

\begin{tabular}{|c|c|c|c|c|c|c|c|c|c|c|c|c|}
\hline \multirow[b]{2}{*}{ Competency } & \multicolumn{2}{|c|}{ Overall } & \multicolumn{2}{|c|}{ Students } & \multicolumn{2}{|c|}{ Faculty/Staff } & \multicolumn{2}{|c|}{ Administrator } & \multicolumn{2}{|c|}{ Alumni } & \multicolumn{2}{|c|}{ Employers } \\
\hline & $\%$ & Rank & $\%$ & Rank & $\%$ & Rank & $\%$ & Rank & $\%$ & Rank & $\%$ & Rank \\
\hline Achieving Objectives & $63 \%$ & 1 & $63 \%$ & 1 & $63 \%$ & 3 & $66 \%$ & 2 & $63 \%$ & 1 & $63 \%$ & 1 \\
\hline Adapting to Change & $61 \%$ & 2 & $58 \%$ & 3 & $64 \%$ & 2 & $64 \%$ & 3 & $59 \%$ & 4 & $63 \%$ & 1 \\
\hline Analyzing \& Solving Problems & $61 \%$ & 2 & $58 \%$ & 3 & $66 \%$ & 1 & $67 \%$ & 1 & $62 \%$ & 2 & $62 \%$ & 3 \\
\hline Making Decisions & $58 \%$ & 4 & $59 \%$ & 2 & $56 \%$ & 4 & $59 \%$ & 4 & $60 \%$ & 3 & $54 \%$ & 7 \\
\hline Communicating Orally & $55 \%$ & 5 & $55 \%$ & 5 & $56 \%$ & 4 & $51 \%$ & 6 & $54 \%$ & 7 & $55 \%$ & 4 \\
\hline Planning \& Organizing & $55 \%$ & 5 & $55 \%$ & 6 & $54 \%$ & 6 & $55 \%$ & 5 & $57 \%$ & 5 & $55 \%$ & 4 \\
\hline Learning \& Self-Development & $53 \%$ & 7 & $53 \%$ & 7 & $52 \%$ & 7 & $48 \%$ & 7 & $55 \%$ & 6 & $55 \%$ & 4 \\
\hline Working Well With Others & $51 \%$ & 8 & $51 \%$ & 8 & $52 \%$ & 7 & $47 \%$ & 8 & $47 \%$ & 9 & $51 \%$ & 8 \\
\hline Generating Ideas \& Innovating & $49 \%$ & 9 & $51 \%$ & 8 & $49 \%$ & 10 & $47 \%$ & 8 & $44 \%$ & 10 & $46 \%$ & 9 \\
\hline Demonstrating Accountability & $46 \%$ & 10 & $45 \%$ & 10 & $49 \%$ & 10 & $43 \%$ & 10 & $48 \%$ & 8 & $46 \%$ & 9 \\
\hline $\begin{array}{l}\text { Upholding Ethical Standards \& } \\
\text { Demonstrating Social } \\
\text { Responsibility }\end{array}$ & $38 \%$ & 11 & $33 \%$ & 12 & $51 \%$ & 9 & $42 \%$ & 11 & $33 \%$ & 13 & $38 \%$ & 12 \\
\hline Leading Others & $36 \%$ & 12 & $40 \%$ & 11 & $32 \%$ & 14 & $40 \%$ & 12 & $34 \%$ & 12 & $33 \%$ & 14 \\
\hline Communicating in Writing & $34 \%$ & 13 & $29 \%$ & 14 & $42 \%$ & 12 & $33 \%$ & 13 & $33 \%$ & 13 & $38 \%$ & 12 \\
\hline $\begin{array}{l}\text { Meeting Customer/Stakeholder } \\
\text { Expectations }\end{array}$ & $32 \%$ & 14 & $31 \%$ & 13 & $28 \%$ & 15 & $33 \%$ & 13 & $35 \%$ & 11 & $39 \%$ & 11 \\
\hline Leveraging Technology & $30 \%$ & 15 & $28 \%$ & 15 & $36 \%$ & 13 & $30 \%$ & 15 & $30 \%$ & 15 & $29 \%$ & 15 \\
\hline $\begin{array}{l}\text { Cultivating a Strategic \& } \\
\text { Entrepreneurial Mindset }\end{array}$ & $23 \%$ & 16 & $24 \%$ & 16 & $20 \%$ & 17 & $26 \%$ & 16 & $23 \%$ & 16 & $23 \%$ & 16 \\
\hline Applying a Global Mindset & $22 \%$ & 17 & $24 \%$ & 16 & $21 \%$ & 16 & $23 \%$ & 17 & $20 \%$ & 17 & $20 \%$ & 17 \\
\hline Influencing Others & $19 \%$ & 18 & $21 \%$ & 18 & $14 \%$ & 19 & $18 \%$ & 18 & $18 \%$ & 18 & $18 \%$ & 19 \\
\hline Exhibiting Resilience & $15 \%$ & 19 & $14 \%$ & 19 & $16 \%$ & 18 & $18 \%$ & 18 & $15 \%$ & 19 & $19 \%$ & 18 \\
\hline Managing the Work of Others & $13 \%$ & 20 & $13 \%$ & 20 & $12 \%$ & 20 & $14 \%$ & 20 & $12 \%$ & 20 & $13 \%$ & 20 \\
\hline
\end{tabular}


Figure 1: Competency Importance Ratings by Criticality Ranking

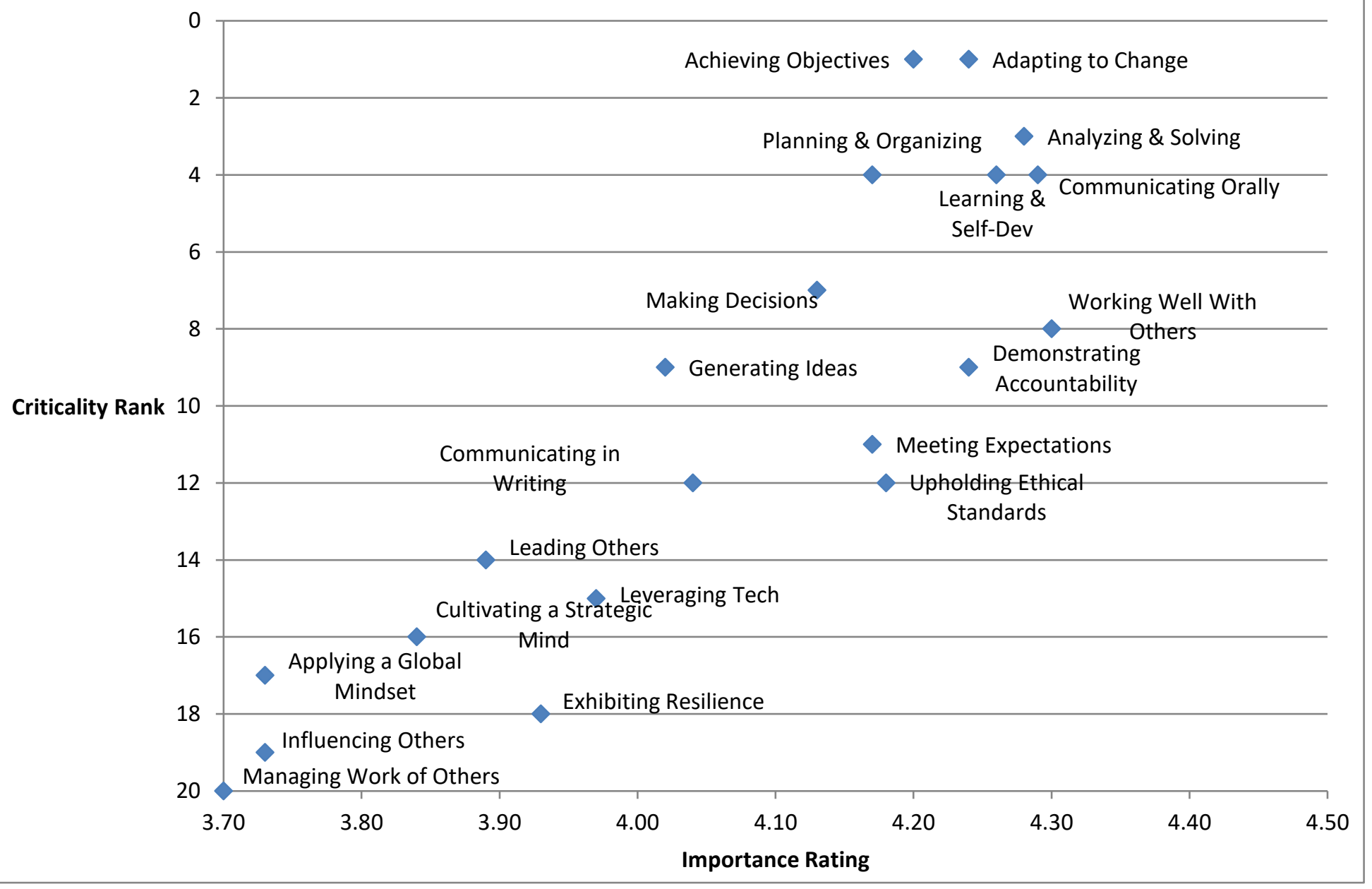




\section{Discussion}

The purpose of the present field study was to determine which competencies were most salient for graduating college students entering the global professional workforce. Data were collected from a large global sample of students, alumni, faculty, staff, and employers. Our study is unique in its goal of establishing competencies relevant for global, rather than national, employability. The validated competencies are consistent with, but expand beyond, those used by others, such as the VALUE rubrics developed by the Association of American Colleges and Universities (Rhodes, 2010), the University of Kent Employability Skills (https://www.kent.ac.uk/ces/student/skills.html), among others. The results show that the most important competencies for new graduates entering the workforce are generally common across geographic regions and industries, with Communicating Orally, Working Well with Others, and Analyzing and Solving Problems as the core set of very important competencies. This finding is consistent with that of Rios et al. (2020), who found in a content analysis of job advertisements that oral and written communication, collaboration, and problem-solving skills were most important for employers. This finding may also be relatively stable; Robles (2012) found that among the most important soft skills at that time were teamwork and communication. One finding that was surprising was how consistently employers, students, and faculty were in ranking the importance of competencies; for example, this consistency was not found in other studies. For example, Karzunina et al. (2018) found that students tended not to understand how employers value various workplace skills. More recently, Succi and Canovi (2020) found that employers continue to rate soft skills as more important than students and graduates do and that the ranking of importance also differs.

Despite the conventional wisdom by some organizations that leadership is a highly important characteristic for all professional employees, competencies such as Managing the Work of Others, Leading Others, and Influencing Others were consistently rated lower in importance by employers across all roles and regions and may not be appropriate as the primary focus of skill development for new graduates. This finding is also consistent with Succi and Canovi (2020), who found that management skills and leadership skills are the lowest ranked by employers among a list of 20 soft skills. This may be due in part because, in most regions of the world, new graduates do not often enter the workforce in leadership roles. Also, Applying a Global Mindset was generally rated as being of low importance. Although cultural sensitivity can be important for some jobs, it may not be imperative for many entry-level professional roles. Alternatively, these leadership and global mindset competencies may be best developed on the job rather than at university or targeted to those students with an interest and an opportunity for global work assignments. Organizations hiring new graduates should consider incorporating the leadership and global mindset competencies into their training programs.

\section{Significance}

The contributions of this field study are substantial. To our knowledge, no competency modeling studies have been reported with a sample size this large and diverse and that have been validated by students, faculty, and employers. The competency survey was administered in over 30 countries in the major regions of the world. Furthermore, gaining the perspective of students, university employees, and private sector employers is rare for a competency modeling project. Additional evidence from the project shows that, for five key competencies, a cross-cultural assessment developed demonstrated measurement invariance, suggesting that assessment scores are consistent between European and Latin American contexts (Herde et al. (2019). Taken together, the diversity and varied experience levels of the sample and the statistical research of the resulting assessment demonstrate that the present competency framework provides greater generalizability than most competency modeling projects that are often idiosyncratic to specific roles, industries, subjects, or levels. 
The identification of key competencies applicable across the world of work can be of significant benefit to universities and students. Many students entering university do not know specifically what career they will pursue, and individuals who begin working in one industry or role often change career paths at some point in their lives. It is extremely valuable to have a taxonomy of competencies that are broadly applicable across industries, roles, and regions to help students prepare for success regardless of the field or region in which they are eventually employed. For instance, university faculty and administrators can use the results of the validation study to develop curricula and programs that will be better able to foster important competencies to ensure that their students are better prepared as they enter the workplace. The rubrics appended to this study provide proficiency levels that can be used to develop student assessments. Students can use the information to help them prepare for job search activities and even career guidance. Embedding the competencies in the curriculum, and assessing those competencies, can provide valuable information to students regarding professional development needed to improve skills acquisition.

Oftentimes, competency models focus on a single organization. Given the scope of this project, this competency model may be used more broadly for hiring decisions and employee development as well as academic curricula. Consistent with Succi and Canovi (2020), we suggest that the results be used to promote further collaboration between employers and academic programs to ensure students are being trained in the most relevant skills and that students understand employers' priorities. Universities and employers can focus on cultivating competencies that are more important for their specific region. Appendix B provides examples of a rubric that can be used to assess development of a particular competency, including descriptions of different proficiency levels that can be used to help assess where individuals currently fall and what they need to do to develop to the next level.

\section{Directions for Research}

Future research would benefit from measuring students' competency levels and following students through multiple time points to track their progress and development. Ideally, a study should attempt to track students for some portion of their academic careers and into their professional careers. Further, future research projects should find ways to include criterion measures for further validation of competency models and measures.

\section{Conclusion}

As competency modeling continues to become more prevalent, broad benefits exist not only for employers but also for academic programs to have a better understanding of what makes for highly competent workers in an increasingly global workforce. The information reported here is a contribution to both the competency modeling literature as well as the academic literature on students' workplace competency development. We developed the project collaboratively with a large network of universities and implemented strategies and recommendations from academic literature during development. The project and the data presented have farreaching implications for academia and industry, including (1) the validation of skills needed for students/graduates to work in the global economy, (2) a mechanism by which students can be evaluated in those skills at least prior to graduation, and (3) a mechanism by which programs can modify curricula to ensure that key competencies are met at graduation. 


\section{References}

Bartram, D. (2005). The great eight competencies: A criterion-centric approach to validation. Journal of Applied Psychology, 90, 1185-1203. https://doi.org/10.1037/0021-9010.90.6.1185

Bhagra, A., \& Sharma, D. K. (2018). Changing paradigm of employability skills in the global business world: A review. IUP Journal of Soft Skills, 12(2), 7-24.

Burke, M. J., \& Dunlap, W. P. (2002). Estimating interrater agreement with the average deviation index: A user's guide. Organizational Research Methods, 5, 159-172. https://doi.org/10.1177/1094428102005002002

Campion, M. A., Fink, A. A., Ruggeberg, B. J., Carr, L., Phillips, G. M., \& Odman, R. B. (2011). Doing competencies well: Best practices in competency modeling. Personnel Psychology, 64, 225-262. https://doi.org/10.1111/j.1744-6570.2010.01207.x

Care, E., Kim, H., Vista, A., Anderson, K., \& Brookings Institution, C. for U. E. (2018). Education system alignment for 21st century skills: Focus on assessment. In Center for Universal Education at The Brookings Institution. Center for Universal Education at The Brookings Institution

Getha-Taylor, H., Hummert, R., Nalbandian, J., \& Silvia, C. (2013). Competency model design and assessment: Findings and future directions. Journal of Public Affairs Education, 19, 141-171. https://doi.org/10.1080/15236803.2013.12001724

Herde, C. N., Lievens, F., Solberg, E. G., Harbaugh, J. L., Strong, M. H., \& Burkholder, G. J. (2019). Situational judgment tests as measures of 21st century skills: Evidence across Europe and Latin America. Journal of Work and Organizational Psychology, 35, 65-74. https://doi.org/10.5093/jwop2019a8

Hodges, D., \& Burchell, N. (2003). Business graduate competencies: Employer's views on importance and performance. Asia-Pacific Journal of Cooperative Education, 4, 16-22.

James, L. R., Demaree, R. G., \& Wolf, G. (1984). Estimating within-group interrater reliability with and without response bias. Journal of Applied Psychology, 69, 85-98. https://doi.org/10.1037/00219010.69.1.85

Jang, H. (2016). Identifying 21st century STEM competencies using workplace data. Journal of Science and Educational Technology, 25, 284-301. https://doi.org/10.1007/s10956-015-9593-1

Karzunina, D., West, J., da Costa, G. M., Phillippou, G., \& Gordon, S. (2018). The global skills gap in the 21st century. QS Intelligence Unit. http://info.qs.com/rs/33.5-VIN535/images/The\%20Global\%20Skills\%20Gap\%2021st\%20Century.pdf.

Lawler, E. E. (1994). From job-based to competency-based organizations. Journal of Organizational Behavior, 15, 3-15. https://doi.org/10.1002/job.4030150103

Lee, Y. (2009). Competencies needed by Korean HRD master's graduates: A comparison between the ASTD WLP competency model and the Korean study. Human Resource Development Quarterly, 20, 107133. https://doi.org/10.1002/hrdq.20010

Lucia, A., \& Lepsinger, R. (1999). The art and science of competency models: Pinpointing critical success factors in organizations. Jossey-Bass/Pfeiffer.

Lunev, A., Petrova, I., Zaripova, V., (2013). Competency-based models of learning for engineers: A comparison. European Journal of Engineering Education, 38:5, 543-555. https://doi.org/10.1080/03043797.2013.824410 
Merisotis, J., \& Hauser, C.B. (2020). A time to reflect on what college should be. Inside Higher Education. https://www.insidehighered.com/views/2020/05/18/colleges-must-deliver-what-matters-moststudents-employers-and-society-opinion.

Mirzazadeh A., Bavarian B., Labaf A., et al. (2013). Medical education curriculum gaps in teaching clinical skills to Iranian undergraduate medical students. Archives of Medical Science, 9, 309-313. https://doi.org/10.5114/aoms.2013.33073

Mirzazadeh, A., Hejri, S. M., Jalili, M., Asghari, F., Labaf, A., Siyahkal, M. S., Afshari, A., \& Saleh. (2014). Defining a competency framework: The first step toward competency-based medical education. Acta Medica Iranica, 52 (9), 710-716.

Paulson, K. (2001). Using competencies to connect the workplace and postsecondary education. New Directions for Institutional Research, 2001 (110), 41-55. https://doi.org/10.1002/ir.10

Prahalad, C.K., \& Hamel, G. (1990). The core competence of the corporation. Harvard Business Review, 68, 79-91.

Rhodes, T. (2010). Assessing outcomes and improving achievement: Tips and tools for using rubrics. Association of American Colleges and Universities.

Rios, J. A., Ling, G., Pugh, R., Becker, D., \& Bacall, A. (2020). Identifying critical 21st century skills for workplace success: A content analysis of job advertisements. Educational Researcher, 49 (2), 80-89. https://doi.org/10.3102/0013189X19890600

Robles, M. M. (2012). Executive perceptions of the top 10 soft skills needed in today's workplace. Business Communication Quarterly, 75 (4), 453-465. https://doiorg.ezp.waldenulibrary.org/10.1177/1080569912460400

Sanchez, J. I., \& Levine, E. L. 2009. What is (or should be) the difference between competency modeling and traditional job analysis? Human Resource Management Review, 19, 53-63. https://doi.org/10.1016/j.hrmr.2008.10.002

Schippmann, J. S., Ash, R. A., Battista, M., Carr, L., Eyde, L. D., Hesketh, B., and Sanchez, J. I. (2000). The practice of competency modeling. Personnel Psychology, 53, 703-740. https://doi.org/10.1111/j.1744-6570.2000.tb00220.x

Schaffhauser, D. (2020). How WGU is filling the skills gap. Campus Technology. https://campustechnology.com/articles/2020/04/20/how-wgu-is-filling-the-skills-gap.aspx.

Stevens, W. S. (2012). A critical review of the science and practice of competency modeling. Integrative Literature Review, 12, 86-107. https://doi.org/10.1177/1534484312456690

Stone, T., Webster, B., \& Schoonover, S. (2013). What do we know about competency modeling? International Journal of Selection and Assessment, 21, 334-338. https://doi.org/10.1111/ijsa.12043

Succi, C., \& Canovi, M. (2020). Soft skills to enhance graduate employability: Comparing students and employers' perceptions. Studies in Higher Education, 45 (9), 1834-1847. https://doiorg.ezp.waldenulibrary.org/10.1080/03075079.2019.1585420

Zemke, R. (1982). Job competencies: Can they help you design better training? Training, 19, 28-31. 


\section{Appendix A}

\section{Competencies \& Definitions}

Achieving Objectives-Accepts or sets demanding individual goals; Meets individual goals and objectives; Takes initiative to seek additional responsibilities, as appropriate; Evaluates work outcomes to ensure quality standards are met.

Adapting to Change-Adjusts work style and interpersonal behavior to fit different situations and environments; Accepts and integrates new ideas and information on their merits; Supports and complies with change initiatives; Works effectively when faced with ambiguity.

Analyzing and Solving Problems-Critically evaluates information and its sources; Identifies gaps in information and seeks appropriate sources to close them; Synthesizes and integrates information into what is already known about a topic; Recognizes patterns in information to identify the bigger picture; Follows best practices and appropriately analyzes quantitative and qualitative data; Identifies and independently solves work problems, as appropriate; Considers multiple approaches when solving problems.

Applying a Global Mindset-Demonstrates interest in, and understanding of, other geographic regions, languages, and cultures; Recognizes own biases and balances local and global perspectives; Works effectively with a global community; Shows an understanding of other countries' standards, certifications, and processes.

Communicating in Writing-Writes professionally using proper grammar, punctuation, spelling, and vocabulary; Writes in an accurate, engaging manner, citing sources as appropriate; Writes in an organized, clear, and concise manner; Creates documents with structure, length, and language appropriate for the topic and audience; Communicates effectively in a non-native written language required for the job.

Communicating Orally-Organizes thoughts and speaks professionally, using proper language and vocabulary; Speaks clearly and displays confidence; Accurately communicates ideas and concepts verbally; Skillfully delivers formal presentations; Actively listens to others and adjusts to their needs; Communicates effectively in a non-native spoken language required for the job.

Cultivating a Strategic and Entrepreneurial Mindset-Understands own organization's offerings and keeps current on the offerings provided by organizations with competing or complementary services and/or products; Aligns own work with the organization's strategy and objectives; Monitors economic, market, social, and societal conditions and trends; Understands and acts upon financial metrics to minimize waste, improve efficiency, and maximize impact; Identifies and strategically addresses opportunities to grow offerings or expand into new areas.

Demonstrating Accountability -Works independently to achieve results; Takes ownership of work and follows through on commitments; Follows work policies, procedures, and guidelines; Appropriately questions authority in a culturally-sensitive manner when necessary; Assimilates to the values, standards, and culture of the organization.

Exhibiting Resilience-Recognizes own emotions and regulates how they are expressed; Maintains focus and productivity under pressure; Prioritizes personal well-being and work-life balance and diminishes the negative effects of stress; Develops and displays confidence in own capabilities despite obstacles or setbacks.

Generating Ideas and Innovating-Generates novel or innovative ideas within own and other areas of expertise; Displays openness to the ideas of others; Proactively identifies opportunities for positive changes to approaches, processes, or products; Demonstrates curiosity and appropriately experiments with new ideas to determine the benefits and risks associated with them. 
Influencing Others-Offers suggestions and advocates for own ideas; Understands how own actions are interpreted by others and creates a positive impression; Navigates the formal and informal organizational structure; Sees issues from others' perspectives and effectively negotiates with them; Adapts style to gain agreement and commitment.

Leading Others-Provides guidance to others; Motivates and encourages others; Willingly shares information, trains and mentors others on areas of expertise; Develops and communicates a compelling vision that is aligned with the organizational strategy.

Learning and Self-Development-Identifies and addresses own knowledge gaps and training needs; Continually expands own knowledge and skills; Applies knowledge and training to professional contexts; Critically evaluates own strengths and weaknesses and pursues development; Seeks feedback and learns from successes and failures; Learns from others and seeks mentors.

Leveraging Technology-Applies technology tools and techniques to gather and store information; Uses technology and visual aids to facilitate and enhance communications; Leverages standard technology and applications to complete work; Applies profession-specific or other specialized applications to complete work; Stays up-to-date on technological changes.

Making Decisions-Identifies available options when making decisions; Evaluates alternative options that have been identified; Makes sound decisions based on available information; Makes decisions in a timely manner.

Managing the Work of Others-Delegates work tasks to others; Monitors performance of team members; Provides others with clear direction and expectations; Provides feedback and coaching to others.

Meeting Customer/Stakeholder Expectations-Understands and meets internal and external customer/stakeholder needs and expectations; Responds to customer/stakeholder requests in a timely manner; Balances customer/stakeholder demands with the organization's objectives.

Planning and Organizing -Sets project objectives, strategies, and milestones; Tracks progress toward project completion; Plans and prioritizes activities, and adjusts plans based on changes; Identifies and obtains the resources needed to accomplish work; Manages time effectively and completes work on schedule.

Upholding Ethical Standards and Demonstrating Social Responsibility-Recognizes ethical challenges and maintains ethical standards; Interacts honestly and transparently with others; Demonstrates integrity and builds trust by keeping promises and admitting mistakes; Acts responsibly to minimize the negative effects of own choices on other individuals, the community, and the environment; Maintains confidentiality of information; Makes sustainable social improvements.

Working Well With Others-Develops and maintains effective working relationships; Interacts effectively with people from different backgrounds; Listens to others and values and incorporates diverse viewpoints; Supports team decisions once they have been made; Adjusts own workload to help meet team commitments, as appropriate; Recognizes and demonstrates empathy for others' feelings, needs, and concerns; Appropriately resolves own work disagreements. 


\section{Appendix B}

\section{Laureate Education Workplace Skills Competency Framework Rubric}

\section{Making Decisions}

\begin{tabular}{|c|c|c|c|}
\hline \multirow[b]{2}{*}{ Behaviors } & \multicolumn{3}{|c|}{ Proficiency Levels } \\
\hline & Level I: Basic & Level II: Intermediate & Level III: Advanced \\
\hline $\begin{array}{l}\text { A. Identifies available } \\
\text { options when making } \\
\text { decisions }\end{array}$ & $\begin{array}{l}\text { Identifies all obvious options } \\
\text { when making decisions }\end{array}$ & $\begin{array}{l}\text { Identifies all obvious options and } \\
\text { some less obvious options when } \\
\text { making decisions }\end{array}$ & $\begin{array}{l}\text { Asks what-if questions to expand } \\
\text { decision-making options beyond the } \\
\text { obvious choices and identifies a } \\
\text { thorough list of viable alternatives }\end{array}$ \\
\hline $\begin{array}{l}\text { B. Evaluates alternative } \\
\text { options that have been } \\
\text { identified }\end{array}$ & $\begin{array}{l}\text { Evaluates the basic advantages } \\
\text { and disadvantages of alternative } \\
\text { options }\end{array}$ & $\begin{array}{l}\text { Evaluates the feasibility, } \\
\text { desirability, and expected } \\
\text { consequences of alternative } \\
\text { options }\end{array}$ & $\begin{array}{l}\text { Thoroughly evaluates the feasibility, } \\
\text { desirability, and potential short- and } \\
\text { long-term consequences of different } \\
\text { options, as well as their impact on } \\
\text { various stakeholder groups }\end{array}$ \\
\hline $\begin{array}{l}\text { C. Makes sound decisions } \\
\text { based on available } \\
\text { information }\end{array}$ & $\begin{array}{l}\text { Considers available information } \\
\text { when making decisions, but may } \\
\text { occasionally over-rely on } \\
\text { intuition or demonstrate some } \\
\text { logical flaws in reasoning }\end{array}$ & $\begin{array}{l}\text { Appropriately balances intuition } \\
\text { with verified information when } \\
\text { making decisions and avoids } \\
\text { logical flaws in reasoning }\end{array}$ & $\begin{array}{l}\text { Makes sound decisions based on the } \\
\text { integration of available information } \\
\text { and intuition gained from relevant } \\
\text { experience; exhibits highly logical } \\
\text { and sound reasoning }\end{array}$ \\
\hline $\begin{array}{l}\text { D. Makes decisions in a } \\
\text { timely manner }\end{array}$ & $\begin{array}{l}\text { Makes straightforward decisions } \\
\text { in a reasonable amount of time }\end{array}$ & $\begin{array}{l}\text { Makes moderately complex } \\
\text { decisions in a timely manner }\end{array}$ & $\begin{array}{l}\text { Makes highly complex decisions in a } \\
\text { timely manner }\end{array}$ \\
\hline
\end{tabular}




\section{Accountability}

\begin{tabular}{|c|c|c|c|}
\hline \multirow[b]{2}{*}{ Behaviors } & \multicolumn{3}{|c|}{ Proficiency Levels } \\
\hline & Level I: Basic & Level II: Intermediate & Level III: Advanced \\
\hline $\begin{array}{l}\text { A. Works } \\
\text { independently to } \\
\text { achieve results }\end{array}$ & $\begin{array}{l}\text { Works under the direction of } \\
\text { others, but does not require } \\
\text { constant supervision }\end{array}$ & $\begin{array}{l}\text { Completes work with minimal } \\
\text { supervision once given initial } \\
\text { instructions }\end{array}$ & $\begin{array}{l}\text { After receiving general guidance, identifies } \\
\text { work that needs to be done and completes } \\
\text { it independently }\end{array}$ \\
\hline $\begin{array}{l}\text { B. Takes ownership } \\
\text { of work and } \\
\text { follows through } \\
\text { on commitments }\end{array}$ & $\begin{array}{l}\text { Demonstrates responsibility for } \\
\text { work assignments and } \\
\text { generally follows through on } \\
\text { work commitments }\end{array}$ & $\begin{array}{l}\text { Takes ownership of work and views } \\
\text { problems that may arise as one's } \\
\text { own responsibility; diligently } \\
\text { follows through on commitments }\end{array}$ & $\begin{array}{l}\text { Demonstrates a strong sense of personal } \\
\text { ownership for work and continually looks } \\
\text { for opportunities to improve work } \\
\text { outcomes; always follows through on } \\
\text { commitments }\end{array}$ \\
\hline $\begin{array}{l}\text { C. Follows work } \\
\text { policies, } \\
\text { procedures, and } \\
\text { guidelines }\end{array}$ & $\begin{array}{l}\text { Understands and follows work } \\
\text { policies, procedures, and } \\
\text { guidelines }\end{array}$ & $\begin{array}{l}\text { Understands and follows all work } \\
\text { policies, procedures, and guidelines, } \\
\text { and encourages others to do } \\
\text { likewise }\end{array}$ & $\begin{array}{l}\text { Understands and follows all work policies, } \\
\text { procedures, and guidelines, and identifies } \\
\text { ways to better align private or public } \\
\text { sector business practices with regulatory } \\
\text { or professional constraints }\end{array}$ \\
\hline $\begin{array}{l}\text { D. Appropriately } \\
\text { questions } \\
\text { authority in a } \\
\text { culturally- } \\
\text { sensitive manner } \\
\text { when necessary }\end{array}$ & $\begin{array}{l}\text { Does not typically question } \\
\text { authority, but does so } \\
\text { appropriately and in a } \\
\text { culturally-sensitive manner if } \\
\text { necessary }\end{array}$ & $\begin{array}{l}\text { Appropriately and constructively } \\
\text { questions authority in a culturally- } \\
\text { sensitive manner to prevent poor } \\
\text { decisions or counterproductive } \\
\text { actions }\end{array}$ & $\begin{array}{l}\text { Appropriately and constructively } \\
\text { questions authority in a culturally- } \\
\text { sensitive manner when faced with an } \\
\text { opportunity to improve decision-making } \\
\text { or functional/organizational performance }\end{array}$ \\
\hline $\begin{array}{l}\text { E. Assimilates to the } \\
\text { values, standards, } \\
\text { and culture of the } \\
\text { organization }\end{array}$ & $\begin{array}{l}\text { Demonstrates respect for, and } \\
\text { understanding of, the values, } \\
\text { standards, and culture of the } \\
\text { organization }\end{array}$ & $\begin{array}{l}\text { Recognizes and adapts behaviors to } \\
\text { the values, standards, and culture of } \\
\text { the organization }\end{array}$ & $\begin{array}{l}\text { Uses in-depth knowledge and } \\
\text { understanding of one's own values, as well } \\
\text { as the organization's values, standards, } \\
\text { and culture, to assimilate to the } \\
\text { organization's expectations }\end{array}$ \\
\hline
\end{tabular}




\section{Working Well with Others}

\begin{tabular}{|c|c|c|c|}
\hline \multirow[b]{2}{*}{ Behaviors } & \multicolumn{3}{|c|}{ Proficiency Levels } \\
\hline & Level I: Basic & Level II: Intermediate & Level III: Advanced \\
\hline $\begin{array}{l}\text { A. Develops and } \\
\text { maintains } \\
\text { effective working } \\
\text { relationships }\end{array}$ & $\begin{array}{l}\text { Develops and maintains } \\
\text { cooperative working } \\
\text { relationships with team } \\
\text { members over the duration } \\
\text { of a project }\end{array}$ & $\begin{array}{l}\text { Develops and maintains effective } \\
\text { working relationships with a variety } \\
\text { of individuals both within and } \\
\text { outside of the immediate work group } \\
\text { for an extended time }\end{array}$ & $\begin{array}{l}\text { Develops highly effective, collaborative } \\
\text { working relationships with a wide network of } \\
\text { individuals, including those with different or } \\
\text { competing priorities and objectives, and } \\
\text { maintains constructive relationships over an } \\
\text { extended period of time }\end{array}$ \\
\hline $\begin{array}{l}\text { B. Interacts } \\
\text { effectively with } \\
\text { people from } \\
\text { different } \\
\text { backgrounds }\end{array}$ & $\begin{array}{l}\text { Works respectfully with } \\
\text { people from different } \\
\text { backgrounds }\end{array}$ & $\begin{array}{l}\text { Appreciates diversity and interacts } \\
\text { effectively with people from different } \\
\text { backgrounds }\end{array}$ & $\begin{array}{l}\text { Welcomes diversity and seeks to develop } \\
\text { working relationships with a wide variety of } \\
\text { people from different backgrounds }\end{array}$ \\
\hline $\begin{array}{l}\text { C. Listens to others } \\
\text { and values and } \\
\text { incorporates } \\
\text { diverse } \\
\text { viewpoints }\end{array}$ & $\begin{array}{l}\text { Listens to others; is } \\
\text { generally open to } \\
\text { considering others' } \\
\text { thoughts and opinions }\end{array}$ & $\begin{array}{l}\text { Carefully listens to others; } \\
\text { understands, respects, and fully } \\
\text { considers diverse thoughts and } \\
\text { opinions }\end{array}$ & $\begin{array}{l}\text { Actively listens to others; solicits and } \\
\text { incorporates diverse thoughts and opinions, } \\
\text { and leverages different viewpoints to improve } \\
\text { the quality of group interactions and decisions }\end{array}$ \\
\hline $\begin{array}{l}\text { Dupports team } \\
\text { decisions once } \\
\text { they have been } \\
\text { made }\end{array}$ & $\begin{array}{l}\text { Follows team decisions } \\
\text { once they have been made }\end{array}$ & $\begin{array}{l}\text { Supports team decisions once they } \\
\text { have been made even if own } \\
\text { recommendations were not adopted }\end{array}$ & $\begin{array}{l}\text { Actively promotes team decisions and } \\
\text { demonstrates strong commitment to the } \\
\text { chosen course of action even if own } \\
\text { recommendations were not adopted }\end{array}$ \\
\hline $\begin{array}{l}\text { E. Adjusts own } \\
\text { workload to help } \\
\text { meet team } \\
\text { commitments, as } \\
\text { appropriate }\end{array}$ & $\begin{array}{l}\text { Keeps up with own work to } \\
\text { help meet team } \\
\text { commitments }\end{array}$ & $\begin{array}{l}\text { Adjusts own workload to } \\
\text { accommodate changing team needs } \\
\text { when asked to do so }\end{array}$ & $\begin{array}{l}\text { Maintains awareness of changing team needs } \\
\text { and proactively adjusts own workload to } \\
\text { ensure team commitments are met }\end{array}$ \\
\hline
\end{tabular}


F. Recognizes and demonstrates empathy for others' feelings, needs, and concerns

G. Appropriately resolves own work

disagreements
Recognizes others' feelings, needs, and concerns

With guidance, han

disagreements with others

in a way that prevents negative situations from

escalating
Takes an active interest in, and demonstrates empathy and support for the feelings, needs, and concerns of others

As appropriate, independently handles own work-related

disagreements and resolves them in an acceptable manner
Attends to emotional cues and engages with others to obtain an understanding of their feelings, needs, and concerns; withholds judgment and provides empathy and support

As appropriate, independently handles own work-related disagreements and resolves them in a constructive and timely manner that enhances working relationships 


\section{Influencing Others}

\begin{tabular}{|c|c|c|c|}
\hline \multirow[b]{2}{*}{ Behaviors } & \multicolumn{3}{|c|}{ Proficiency Levels } \\
\hline & Level I: Basic & Level II: Intermediate & Level III: Advanced \\
\hline $\begin{array}{l}\text { A. Offers } \\
\text { suggestions and } \\
\text { advocates for } \\
\text { own ideas }\end{array}$ & $\begin{array}{l}\text { Makes suggestions or offers } \\
\text { ideas when asked and } \\
\text { generates an appropriate } \\
\text { response to opposition }\end{array}$ & $\begin{array}{l}\text { Confidently makes suggestions and } \\
\text { voices ideas; anticipates obvious } \\
\text { objections to ideas and prepares } \\
\text { appropriate responses accordingly }\end{array}$ & $\begin{array}{l}\text { Voices ideas with conviction and actively } \\
\text { works to influence others to gain support; } \\
\text { anticipates a wide variety of oppositions to } \\
\text { ideas and presents solid arguments to } \\
\text { address these challenges }\end{array}$ \\
\hline $\begin{array}{l}\text { B. Understands } \\
\text { how own actions } \\
\text { are interpreted } \\
\text { by others and } \\
\text { creates a positive } \\
\text { impression }\end{array}$ & $\begin{array}{l}\text { Is generally aware of how own } \\
\text { actions are interpreted by } \\
\text { others and attempts to create } \\
\text { a positive impression }\end{array}$ & $\begin{array}{l}\text { Is aware of how own actions are } \\
\text { interpreted by others and actively } \\
\text { manages behaviors to create a } \\
\text { positive impression }\end{array}$ & $\begin{array}{l}\text { Is aware of how own actions are } \\
\text { interpreted by others and actively manages } \\
\text { behaviors to establish a long-term positive } \\
\text { impression }\end{array}$ \\
\hline $\begin{array}{l}\text { C. Navigates the } \\
\text { formal and } \\
\text { informal } \\
\text { organizational } \\
\text { structure }\end{array}$ & $\begin{array}{l}\text { Develops an awareness of the } \\
\text { formal and informal } \\
\text { organizational structure and } \\
\text { key internal stakeholders }\end{array}$ & $\begin{array}{l}\text { Is knowledgeable regarding the } \\
\text { organization's formal and informal } \\
\text { structure and internal stakeholders } \\
\text { and navigates organizational politics } \\
\text { to avoid unnecessary impediments to } \\
\text { accomplishing work }\end{array}$ & $\begin{array}{l}\text { Has a thorough knowledge of the } \\
\text { organization's formal and informal } \\
\text { structure and internal and external } \\
\text { stakeholders; leverages organizational } \\
\text { politics to more effectively accomplish } \\
\text { work and influence outcomes }\end{array}$ \\
\hline $\begin{array}{l}\text { D. Sees issues from } \\
\text { others' } \\
\text { perspectives and } \\
\text { effectively } \\
\text { negotiates with } \\
\text { them }\end{array}$ & $\begin{array}{l}\text { Sees issues from others' } \\
\text { perspectives and attempts to } \\
\text { negotiate with them }\end{array}$ & $\begin{array}{l}\text { Sees issues from others' perspectives } \\
\text { and negotiates with them by exploring } \\
\text { a range of possibilities, recognizing } \\
\text { the need for mutual concessions so all } \\
\text { parties feel satisfied with the outcome }\end{array}$ & $\begin{array}{l}\text { Sees issues from others' perspectives and } \\
\text { effectively negotiates with individuals } \\
\text { internal and external to the organization } \\
\text { by adopting a range of approaches and } \\
\text { maintaining open communication } \\
\text { throughout the process to ensure all } \\
\text { parties feel positive about the outcome }\end{array}$ \\
\hline
\end{tabular}


E. Adapts style to gain agreement and commitment
Uses information, facts, and data to attempt to influence others
Adapts style and approach to align with others' needs and interests in order to effectively influence, reach agreement, and gain commitment from others
Skillfully guides conversations to uncover paths to agreement that leave all parties fully committed to the chosen course of action 


\section{Communicating Orally}

\begin{tabular}{|c|c|c|c|}
\hline \multirow[b]{2}{*}{ Behaviors } & \multicolumn{3}{|c|}{ Proficiency Levels } \\
\hline & Level I: Basic & Level II: Intermediate & Level III: Advanced \\
\hline $\begin{array}{l}\text { A. Organizes } \\
\text { thoughts and } \\
\text { speaks } \\
\text { professionally, } \\
\text { using proper } \\
\text { language and } \\
\text { vocabulary }\end{array}$ & $\begin{array}{l}\text { Uses language and vocabulary } \\
\text { appropriate for a professional } \\
\text { work environment }\end{array}$ & $\begin{array}{l}\text { Develops and synthesizes ideas } \\
\text { to explain or discuss } \\
\text { information in an organized } \\
\text { manner, using precise } \\
\text { language and vocabulary }\end{array}$ & $\begin{array}{l}\text { Develops and synthesizes ideas to skillfully organize } \\
\text { information, using language and vocabulary that is } \\
\text { specifically tailored to the audience and maximizes } \\
\text { understanding }\end{array}$ \\
\hline $\begin{array}{l}\text { B. Speaks clearly } \\
\text { and displays } \\
\text { confidence }\end{array}$ & $\begin{array}{l}\text { Speaks clearly most of the } \\
\text { time, but may lack confidence } \\
\text { at times }\end{array}$ & $\begin{array}{l}\text { Speaks clearly with } \\
\text { appropriate pacing and } \\
\text { displays confidence when } \\
\text { speaking about familiar topics }\end{array}$ & $\begin{array}{l}\text { Speaks clearly with appropriate pacing, pauses, } \\
\text { volume changes, and emphasis, and displays } \\
\text { confidence when speaking about a wide variety of } \\
\text { topics }\end{array}$ \\
\hline $\begin{array}{l}\text { C. Accurately } \\
\text { communicates } \\
\text { ideas and } \\
\text { concepts } \\
\text { verbally }\end{array}$ & $\begin{array}{l}\text { Accurately communicates } \\
\text { basic information verbally }\end{array}$ & $\begin{array}{l}\text { Accurately communicates } \\
\text { ambiguous or somewhat } \\
\text { complex concepts and ideas } \\
\text { verbally }\end{array}$ & $\begin{array}{l}\text { Accurately and concisely communicates ambiguous or } \\
\text { complex concepts and ideas in an easy-to-understand } \\
\text { manner }\end{array}$ \\
\hline $\begin{array}{l}\text { D. Skillfully } \\
\text { delivers } \\
\text { formal } \\
\text { presentations }\end{array}$ & $\begin{array}{l}\text { Successfully delivers formal } \\
\text { presentations to internal } \\
\text { groups, but may need } \\
\text { additional polish and skill }\end{array}$ & $\begin{array}{l}\text { Skillfully delivers engaging } \\
\text { formal presentations to } \\
\text { internal and external groups }\end{array}$ & $\begin{array}{l}\text { Skillfully delivers engaging and influential formal } \\
\text { presentations to internal and external groups, easily } \\
\text { adapting to different settings (e.g., conferences, } \\
\text { department meetings) }\end{array}$ \\
\hline
\end{tabular}


E. Actively

listens to

others and

adjusts to

their needs

F. Communicates

effectively in a

non-native

spoken

language

required for

the job
Listens to others and responds

to their questions or requests

.

as a basic command of a

non-native spoken language

required for the job; can be

understood by others but

speaks in a rudimentary way
Actively listens to others,

checks their understanding,

responds to questions, and

adjusts content or style if

necessary

Has an intermediate command

of a non-native spoken

language required for the job;

is able to communicate with an

accurate and varied vocabulary
Actively listens to others, anticipates their needs, monitors their understanding via verbal and nonverbal cues, responds to questions, and adjusts content or style as necessary

\section{Has a thorough command of a non-native spoken} language required for the job; is able to speak precisely with nuanced language 


\section{Communicating in Writing}

\begin{tabular}{|c|c|c|c|}
\hline \multirow[b]{2}{*}{ Behaviors } & \multicolumn{3}{|c|}{ Proficiency Levels } \\
\hline & Level I: Basic & Level II: Intermediate & Level III: Advanced \\
\hline $\begin{array}{l}\text { A. Writes } \\
\text { professionally } \\
\text { using proper } \\
\text { grammar, } \\
\text { punctuation, } \\
\text { spelling, and } \\
\text { vocabulary }\end{array}$ & $\begin{array}{l}\text { Grammar, punctuation, } \\
\text { spelling, and vocabulary are } \\
\text { typically correct in formal } \\
\text { documents, but may be too } \\
\text { casual in informal } \\
\text { communications }\end{array}$ & $\begin{array}{l}\text { Uses proper grammar, } \\
\text { punctuation, spelling, and } \\
\text { vocabulary in all communications }\end{array}$ & $\begin{array}{l}\text { Uses proper grammar, punctuation, spelling, } \\
\text { and vocabulary, striking the appropriate } \\
\text { professional tone for different types of } \\
\text { communications }\end{array}$ \\
\hline $\begin{array}{l}\text { B. Writes in an } \\
\text { accurate, } \\
\text { engaging } \\
\text { manner, citing } \\
\text { sources as } \\
\text { appropriate }\end{array}$ & $\begin{array}{l}\text { Accurately conveys basic } \\
\text { information in a way that } \\
\text { engages audiences interested in } \\
\text { the topic, citing sources as } \\
\text { appropriate }\end{array}$ & $\begin{array}{l}\text { Accurately conveys ambiguous or } \\
\text { somewhat complex information in } \\
\text { a way that engages audiences both } \\
\text { interested and new to the topic, } \\
\text { citing sources as appropriate }\end{array}$ & $\begin{array}{l}\text { Accurately conveys highly complex and } \\
\text { ambiguous information in a way that } \\
\text { engages a variety of audiences regardless of } \\
\text { the topic, citing sources as appropriate }\end{array}$ \\
\hline $\begin{array}{l}\text { C. Writes in an } \\
\text { organized, clear, } \\
\text { and concise } \\
\text { manner }\end{array}$ & $\begin{array}{l}\text { Writing is understandable, but } \\
\text { not always presented in an } \\
\text { organized, concise, or cohesive } \\
\text { manner }\end{array}$ & $\begin{array}{l}\text { On familiar topics, writing is well } \\
\text { organized, clear, concise, and } \\
\text { supports goals }\end{array}$ & $\begin{array}{l}\text { Regardless of the topic, writing is organized } \\
\text { with a clear structure that logically, } \\
\text { concisely, and purposefully presents ideas } \\
\text { and supports goals }\end{array}$ \\
\hline $\begin{array}{l}\text { D. Creates } \\
\text { documents with } \\
\text { structure, } \\
\text { length, and } \\
\text { language } \\
\text { appropriate for } \\
\text { the topic and } \\
\text { audience }\end{array}$ & $\begin{array}{l}\text { Structure, length, language, and } \\
\text { degree of detail match own level } \\
\text { of knowledge rather than the } \\
\text { audience's needs }\end{array}$ & $\begin{array}{l}\text { On familiar topics, structure, } \\
\text { length, language, and level of } \\
\text { detail match the audience's needs }\end{array}$ & $\begin{array}{l}\text { Regardless of topic or audience, writing style, } \\
\text { structure, length, language, and level of } \\
\text { detail anticipate the audience's needs }\end{array}$ \\
\hline
\end{tabular}


E. Communicates effectively in a non-native

written

language

required for the job

Has a basic command of a non-

native written language required

for the job; can create simple,

accurate documents with the aid

of a dictionary or translation

device

Has an intermediate command of

a non-native written language

required for the job; can create

accurate documents using correct

subject-verb agreement and verb

tense without help
Has a thorough command of a non-native written language required for the job; is able to create complex accurate documents that include precise, nuanced vocabulary and phrasing 


\section{Learning and Self-Development}

\begin{tabular}{|c|c|c|c|}
\hline \multirow[b]{2}{*}{ Behaviors } & \multicolumn{3}{|c|}{ Proficiency Levels } \\
\hline & Level I: Basic & Level II: Intermediate & Level III: Advanced \\
\hline $\begin{array}{l}\text { A. Identifies and } \\
\text { addresses own } \\
\text { knowledge gaps } \\
\text { and training } \\
\text { needs }\end{array}$ & $\begin{array}{l}\text { Recognizes own knowledge gaps } \\
\text { and training needs once they have } \\
\text { been pointed out by others, and } \\
\text { exerts some effort to close those } \\
\text { gaps }\end{array}$ & $\begin{array}{l}\text { Independently recognizes own } \\
\text { knowledge gaps and training needs } \\
\text { in area of expertise, and exerts } \\
\text { deliberate effort to close any gaps }\end{array}$ & $\begin{array}{l}\text { Proactively seeks to identify knowledge } \\
\text { gaps and training needs in own and related } \\
\text { areas of expertise, and systematically } \\
\text { exerts effort to close those gaps }\end{array}$ \\
\hline $\begin{array}{l}\text { B. Continually } \\
\text { expands own } \\
\text { knowledge and } \\
\text { skills }\end{array}$ & $\begin{array}{l}\text { Attends mandatory } \\
\text { courses/training programs and } \\
\text { reads assigned documents to } \\
\text { expand skills and knowledge in } \\
\text { own field of expertise }\end{array}$ & $\begin{array}{l}\text { Independently seeks opportunities } \\
\text { to attend optional relevant training } \\
\text { programs and searches for } \\
\text { supplemental reading to expand } \\
\text { skills and knowledge in own field of } \\
\text { expertise }\end{array}$ & $\begin{array}{l}\text { Independently develops informal or } \\
\text { formal self-learning programs in a } \\
\text { strategic manner to ensure a constant } \\
\text { expansion of knowledge and skills in own } \\
\text { and related fields of expertise }\end{array}$ \\
\hline $\begin{array}{l}\text { C. Applies } \\
\text { knowledge and } \\
\text { training to } \\
\text { professional } \\
\text { contexts }\end{array}$ & $\begin{array}{l}\text { Is generally able to apply new } \\
\text { knowledge to work tasks, but may } \\
\text { have difficulty when the } \\
\text { application of knowledge to the } \\
\text { task is less obvious or out of } \\
\text { context }\end{array}$ & $\begin{array}{l}\text { Frequently and effectively applies } \\
\text { new knowledge to work tasks }\end{array}$ & $\begin{array}{l}\text { Consistently seeks and identifies novel } \\
\text { ways to apply relevant knowledge to a wide } \\
\text { variety of work tasks and practical } \\
\text { applications }\end{array}$ \\
\hline $\begin{array}{l}\text { D. Critically } \\
\text { evaluates own } \\
\text { strengths and } \\
\text { weaknesses and } \\
\text { pursues } \\
\text { development }\end{array}$ & $\begin{array}{l}\text { Recognizes own obvious strengths } \\
\text { and weaknesses, and works to } \\
\text { improve areas requiring } \\
\text { immediate development }\end{array}$ & $\begin{array}{l}\text { Regularly evaluates own strengths } \\
\text { and weaknesses and pursues } \\
\text { opportunities to develop in } \\
\text { necessary areas }\end{array}$ & $\begin{array}{l}\text { Systematically evaluates own strengths } \\
\text { and weaknesses, critically evaluating both } \\
\text { obvious and subtle areas for development } \\
\text { and strategically pursuing opportunities } \\
\text { for both short and long-term professional } \\
\text { development }\end{array}$ \\
\hline
\end{tabular}




\begin{tabular}{|l|l|l|l|}
$\begin{array}{l}\text { E. Seeks feedback } \\
\text { and learns from } \\
\text { successes and } \\
\text { failures }\end{array}$ & $\begin{array}{l}\text { Listens to, understands, and } \\
\text { accepts both positive and negative } \\
\text { feedback offered by team } \\
\text { members }\end{array}$ & $\begin{array}{l}\text { Solicits feedback from team } \\
\text { members; evaluates and reflects on } \\
\text { negative feedback to understand } \\
\text { what went wrong and identify } \\
\text { lessons to apply in the future }\end{array}$ & $\begin{array}{l}\text { Routinely solicits and integrates feedback } \\
\text { from team members and other } \\
\text { professional contacts; thoroughly } \\
\text { evaluates and reflects on both successes } \\
\text { and failures to improve future } \\
\text { performance }\end{array}$ \\
\hline $\begin{array}{l}\text { F. Learns from } \\
\text { others and } \\
\text { seeks mentors }\end{array}$ & $\begin{array}{l}\text { Identifies lessons from the } \\
\text { experiences of others and } \\
\text { incorporates those lessons into } \\
\text { own work behaviors }\end{array}$ & $\begin{array}{l}\text { Learns from others' experiences } \\
\text { and seeks work-related advice and } \\
\text { guidance from experienced } \\
\text { professionals }\end{array}$ & $\begin{array}{l}\text { Willingly solicits advice and learns from } \\
\text { others; actively seeks and develops } \\
\text { mentoring relationships with experienced } \\
\text { professionals }\end{array}$ \\
\hline
\end{tabular}




\section{Analyzing and Solving Problems}

\begin{tabular}{|c|c|c|c|}
\hline \multirow[b]{2}{*}{ Behaviors } & \multicolumn{3}{|c|}{ Proficiency Levels } \\
\hline & Level I: Basic & Level II: Intermediate & Level III: Advanced \\
\hline $\begin{array}{l}\text { A. Critically } \\
\text { evaluates } \\
\text { information } \\
\text { and its } \\
\text { sources }\end{array}$ & $\begin{array}{l}\text { Considers the source, accuracy, } \\
\text { and value of information before } \\
\text { accepting and using it }\end{array}$ & $\begin{array}{l}\text { Establishes basic criteria to } \\
\text { evaluate the source, accuracy, } \\
\text { and value of information, and } \\
\text { only uses information that } \\
\text { passes these criteria }\end{array}$ & $\begin{array}{l}\text { Establishes advanced criteria to ensure that } \\
\text { information comes only from credible, reliable } \\
\text { sources }\end{array}$ \\
\hline $\begin{array}{l}\text { B. Identifies } \\
\text { gaps in } \\
\text { information } \\
\text { and seeks } \\
\text { appropriate } \\
\text { sources to } \\
\text { close them }\end{array}$ & $\begin{array}{l}\text { Identifies when there are } \\
\text { obvious gaps in information and } \\
\text { seeks appropriate sources to } \\
\text { address those gaps }\end{array}$ & $\begin{array}{l}\text { Identifies and seeks to close } \\
\text { obvious and subtle gaps in } \\
\text { information with appropriate } \\
\text { sources }\end{array}$ & $\begin{array}{l}\text { Recognizes and reconciles all meaningful gaps in } \\
\text { available information with appropriate sources }\end{array}$ \\
\hline $\begin{array}{l}\text { C. Synthesizes } \\
\text { and integrates } \\
\text { information } \\
\text { into what is } \\
\text { already } \\
\text { known about } \\
\text { a topic }\end{array}$ & $\begin{array}{l}\text { Synthesizes and integrates basic } \\
\text { information into what is already } \\
\text { known about a topic }\end{array}$ & $\begin{array}{l}\text { Synthesizes and integrates fairly } \\
\text { complex or ambiguous } \\
\text { information into what is already } \\
\text { known about a topic }\end{array}$ & $\begin{array}{l}\text { Expertly integrates and synthesizes highly } \\
\text { complex and ambiguous information into what is } \\
\text { already known about a topic }\end{array}$ \\
\hline $\begin{array}{l}\text { D. Recognizes } \\
\text { patterns in } \\
\text { information } \\
\text { to identify the } \\
\text { bigger picture }\end{array}$ & $\begin{array}{l}\text { Identifies basic patterns in } \\
\text { information but tends to view } \\
\text { data points separately }\end{array}$ & $\begin{array}{l}\text { Recognizes that patterns exist in } \\
\text { seemingly unrelated qualitative } \\
\text { or quantitative data and works to } \\
\text { determine the relationship } \\
\text { between them to uncover the } \\
\text { bigger picture }\end{array}$ & $\begin{array}{l}\text { Analyzes complex relationships in information not } \\
\text { outwardly related, identifying subtle relationships } \\
\text { and patterns to uncover the bigger picture }\end{array}$ \\
\hline
\end{tabular}


E. Follows best practices and appropriately analyzes quantitative and qualitative data

F. Identifies and independently solves work problems, as appropriate

G. Considers multiple approaches when solving problems
Follows best practices and performs basic logical, mathematical, or linguistic analyses of information

\section{Identifies and alerts others about} existing problems;

independently solves basic work problems and seeks guidance to solve more complex issues

Considers multiple approaches when solving problems but tends to rely on well-tested or traditional solutions
Applies principles of relevant

theory and functional best practices to the analysis of quantitative and qualitative data; performs intermediate logical, mathematical, or linguistic analyses of information

Identifies and alerts others about current or potential problems or obstacles; independently solves fairly complex work problems, as appropriate

\section{Considers alternative}

perspectives and approaches when solving problems and is willing to try a new approach
Fully integrates and applies complex theory, best practices, and sound rationale to the analysis of quantitative and qualitative data; performs advanced logical, mathematical, or linguistic analyses to derive full value from information

Effectively anticipates problems and obstacles and works to prevent them; independently solves ambiguous and complex work problems, viewing them as opportunities to learn and improve work processes

Identifies new ways to solve problems in order to better meet the needs of the situation 


\section{Generating Ideas and Innovating}

\begin{tabular}{|c|c|c|c|}
\hline \multirow[b]{2}{*}{ Behaviors } & \multicolumn{3}{|c|}{ Proficiency Levels } \\
\hline & Level I: Basic & Level II: Intermediate & Level III: Advanced \\
\hline $\begin{array}{l}\text { A. Generates novel or } \\
\text { innovative ideas } \\
\text { within own and } \\
\text { other areas of } \\
\text { expertise }\end{array}$ & $\begin{array}{l}\text { Generates basic, and } \\
\text { occasionally novel, ideas } \\
\text { within own area of expertise }\end{array}$ & $\begin{array}{l}\text { Generates fairly innovative ideas } \\
\text { within own area of expertise }\end{array}$ & $\begin{array}{l}\text { Generates innovative ideas in a variety } \\
\text { of different areas of expertise }\end{array}$ \\
\hline $\begin{array}{l}\text { B. Displays openness } \\
\text { to the ideas of } \\
\text { others }\end{array}$ & $\begin{array}{l}\text { Demonstrates receptiveness to } \\
\text { the ideas of others }\end{array}$ & $\begin{array}{l}\text { Recognizes and builds upon the ideas } \\
\text { of others }\end{array}$ & $\begin{array}{l}\text { Actively encourages and stimulates idea } \\
\text { generation in others }\end{array}$ \\
\hline $\begin{array}{l}\text { C. Proactively } \\
\text { identifies } \\
\text { opportunities for } \\
\text { positive changes to } \\
\text { approaches, } \\
\text { processes, or } \\
\text { products }\end{array}$ & $\begin{array}{l}\text { Identifies occasional } \\
\text { opportunities for positive } \\
\text { changes to existing } \\
\text { approaches, processes, or } \\
\text { products }\end{array}$ & $\begin{array}{l}\text { Proactively identifies opportunities } \\
\text { for positive changes to existing } \\
\text { approaches, processes, and products, } \\
\text { as well as identifies some prospects } \\
\text { for impactful innovation }\end{array}$ & $\begin{array}{l}\text { Proactively identifies numerous } \\
\text { opportunities for positive changes to } \\
\text { existing approaches, processes, and } \\
\text { products, highlighting multiple avenues } \\
\text { for impactful innovation }\end{array}$ \\
\hline $\begin{array}{l}\text { D. Demonstrates } \\
\text { curiosity and } \\
\text { appropriately } \\
\text { experiments with } \\
\text { new ideas to } \\
\text { determine the } \\
\text { benefits and risks } \\
\text { associated with } \\
\text { them }\end{array}$ & $\begin{array}{l}\text { Considers the more obvious } \\
\text { potential benefits and risks } \\
\text { associated with a new idea, } \\
\text { and pursues the idea if it } \\
\text { seems feasible }\end{array}$ & $\begin{array}{l}\text { Considers a broad range of potential } \\
\text { benefits and risks associated with a } \\
\text { new idea; asks questions and engages } \\
\text { in basic experimentation to help } \\
\text { determine if a new idea should be } \\
\text { pursued }\end{array}$ & $\begin{array}{l}\text { Considers the full range of potential } \\
\text { benefits and risks associated with a new } \\
\text { idea, and engages in thorough } \\
\text { experimentation to determine the best } \\
\text { approach }\end{array}$ \\
\hline
\end{tabular}




\section{Planning and Organizing}

\begin{tabular}{|c|c|c|c|}
\hline \multirow[b]{2}{*}{ Behaviors } & \multicolumn{3}{|c|}{ Proficiency Levels } \\
\hline & Level I: Basic & Level II: Intermediate & Level III: Advanced \\
\hline $\begin{array}{l}\text { A. Sets project } \\
\text { objectives, } \\
\text { strategies, and } \\
\text { milestones }\end{array}$ & $\begin{array}{l}\text { Sets broad project objectives } \\
\text { and strategies }\end{array}$ & $\begin{array}{l}\text { Sets specific project objectives and } \\
\text { strategies, and identifies major } \\
\text { milestones }\end{array}$ & $\begin{array}{l}\text { Sets specific project objectives and } \\
\text { strategies, and defines success for each; } \\
\text { identifies and documents all relevant } \\
\text { milestones }\end{array}$ \\
\hline $\begin{array}{l}\text { B. Tracks progress } \\
\text { toward project } \\
\text { completion }\end{array}$ & $\begin{array}{l}\text { Maintains a general awareness } \\
\text { of project progress and status }\end{array}$ & $\begin{array}{l}\text { Regularly monitors and } \\
\text { communicates project status using } \\
\text { basic metrics or key performance } \\
\text { indicators }\end{array}$ & $\begin{array}{l}\text { Continually monitors and communicates } \\
\text { project status using advanced metrics and } \\
\text { key performance indicators }\end{array}$ \\
\hline $\begin{array}{l}\text { C. Plans and } \\
\text { prioritizes } \\
\text { activities, and } \\
\text { adjusts plans } \\
\text { based on } \\
\text { changes }\end{array}$ & $\begin{array}{l}\text { Plans and prioritizes activities } \\
\text { when beginning work; } \\
\text { evaluates and adjusts plans to } \\
\text { account for changing priorities, } \\
\text { but may struggle when a major } \\
\text { shift in priorities occurs }\end{array}$ & $\begin{array}{l}\text { Plans and prioritizes activities in } \\
\text { advance of beginning work; } \\
\text { evaluates and adjusts plans to } \\
\text { account for changing priorities } \\
\text { without much loss of productivity or } \\
\text { focus }\end{array}$ & $\begin{array}{l}\text { Thoroughly plans and prioritizes activities } \\
\text { well in advance of beginning work; } \\
\text { effectively evaluates and adjusts plans to } \\
\text { account for changing priorities without } \\
\text { losing productivity or focus }\end{array}$ \\
\hline $\begin{array}{l}\text { D. Identifies and } \\
\text { obtains the } \\
\text { resources } \\
\text { needed to } \\
\text { accomplish } \\
\text { work }\end{array}$ & $\begin{array}{l}\text { Correctly identifies most } \\
\text { necessary resources to } \\
\text { accomplish work and generally } \\
\text { ensures those resources will be } \\
\text { available when needed }\end{array}$ & $\begin{array}{l}\text { Correctly identifies and obtains all } \\
\text { necessary resources to accomplish } \\
\text { work and secures resources in a } \\
\text { timely manner }\end{array}$ & $\begin{array}{l}\text { Correctly identifies and obtains all necessary } \\
\text { resources to accomplish work well in advance, } \\
\text { and secures resources in a way that effectively } \\
\text { balances own needs with those of others in } \\
\text { the organization as well as time and cost }\end{array}$ \\
\hline $\begin{array}{l}\text { E. Manages time } \\
\text { effectively and } \\
\text { completes work } \\
\text { on schedule }\end{array}$ & $\begin{array}{l}\text { Manages time acceptably and } \\
\text { typically completes work on } \\
\text { schedule }\end{array}$ & $\begin{array}{l}\text { Manages time effectively; acts quickly } \\
\text { to complete high-priority and urgent } \\
\text { tasks and completes remaining tasks } \\
\text { in a reasonable amount of time }\end{array}$ & $\begin{array}{l}\text { Manages time effectively; acts with a strong } \\
\text { sense of urgency to complete all assigned } \\
\text { work, effectively matching pacing to the } \\
\text { requirements of the task }\end{array}$ \\
\hline
\end{tabular}




\section{Achieving Objectives}

\begin{tabular}{|c|c|c|c|}
\hline \multirow[b]{2}{*}{ Behaviors } & \multicolumn{3}{|c|}{ Proficiency Levels } \\
\hline & Level I: Basic & Level II: Intermediate & Level III: Advanced \\
\hline $\begin{array}{l}\text { A. Accepts or sets } \\
\text { demanding individual } \\
\text { goals }\end{array}$ & $\begin{array}{l}\text { Accepts moderately } \\
\text { challenging individual goals } \\
\text { and exerts effort to try to } \\
\text { achieve them }\end{array}$ & $\begin{array}{l}\text { Sets or accepts demanding } \\
\text { individual goals and exerts extra } \\
\text { effort, when needed, to try to } \\
\text { achieve them }\end{array}$ & $\begin{array}{l}\text { Seeks demanding individual goals and } \\
\text { consistently exerts extra effort to try to } \\
\text { achieve them }\end{array}$ \\
\hline $\begin{array}{l}\text { B. Meets individual goals } \\
\text { and objectives }\end{array}$ & $\begin{array}{l}\text { Typically meets fundamental } \\
\text { individual goals and objectives }\end{array}$ & $\begin{array}{l}\text { Consistently meets challenging } \\
\text { individual goals and objectives }\end{array}$ & $\begin{array}{l}\text { Regularly exceeds challenging } \\
\text { individual goals and objectives }\end{array}$ \\
\hline $\begin{array}{l}\text { C. Takes initiative to seek } \\
\text { additional } \\
\text { responsibilities, as } \\
\text { appropriate }\end{array}$ & $\begin{array}{l}\text { After completing own work, } \\
\text { takes on additional } \\
\text { responsibilities when it is } \\
\text { convenient to do so }\end{array}$ & $\begin{array}{l}\text { In addition to completing own } \\
\text { work, volunteers for appropriate } \\
\text { additional responsibilities within } \\
\text { own work area }\end{array}$ & $\begin{array}{l}\text { In addition to completing own work, } \\
\text { proactively seeks out additional } \\
\text { opportunities and stretch assignments } \\
\text { both inside and outside of own work } \\
\text { area, as appropriate }\end{array}$ \\
\hline $\begin{array}{l}\text { D. Evaluates work } \\
\text { outcomes to ensure } \\
\text { quality standards are } \\
\text { met }\end{array}$ & $\begin{array}{l}\text { Evaluates work outcomes to } \\
\text { ensure basic quality standards } \\
\text { are met }\end{array}$ & $\begin{array}{l}\text { Regularly evaluates work } \\
\text { outcomes to ensure work } \\
\text { delivered meets high-quality } \\
\text { standards }\end{array}$ & $\begin{array}{l}\text { Consistently evaluates work outcomes } \\
\text { to ensure work delivered meets high- } \\
\text { quality standards; does not compromise } \\
\text { on quality even when under pressure to } \\
\text { cut corners }\end{array}$ \\
\hline
\end{tabular}




\section{Customer/Stakeholder Orientation}

\begin{tabular}{|c|c|c|c|}
\hline \multirow[b]{2}{*}{ Behaviors } & \multicolumn{3}{|c|}{ Proficiency Levels } \\
\hline & Level I: Basic & Level II: Intermediate & Level III: Advanced \\
\hline $\begin{array}{l}\text { A. Understands and } \\
\text { meets internal and } \\
\text { external } \\
\text { customer/stakeholder } \\
\text { needs and } \\
\text { expectations }\end{array}$ & $\begin{array}{l}\text { Understands and meets stated } \\
\text { internal and external } \\
\text { customer/stakeholder needs } \\
\text { and expectations }\end{array}$ & $\begin{array}{l}\text { Proactively works with internal } \\
\text { and external } \\
\text { customers/stakeholders to fully } \\
\text { understand and meet their needs } \\
\text { and expectations, including those } \\
\text { not directly expressed }\end{array}$ & $\begin{array}{l}\text { Consistently delivers products or } \\
\text { services that exceed internal and } \\
\text { external customers'/stakeholders' } \\
\text { needs and expectations, including those } \\
\text { not directly expressed }\end{array}$ \\
\hline $\begin{array}{l}\text { B. Responds to } \\
\text { customer/stakeholder } \\
\text { requests in a timely } \\
\text { manner }\end{array}$ & $\begin{array}{l}\text { Responds to internal and } \\
\text { external customer/stakeholder } \\
\text { requests within the required } \\
\text { timeframe }\end{array}$ & $\begin{array}{l}\text { Eagerly responds to internal and } \\
\text { external customer/stakeholder } \\
\text { requests in a timely manner }\end{array}$ & $\begin{array}{l}\text { Responds to internal and external } \\
\text { customer/stakeholder requests with a } \\
\text { sense of urgency; conveys to } \\
\text { customers/stakeholders that they are a } \\
\text { top priority by finding resourceful ways } \\
\text { to address their needs }\end{array}$ \\
\hline $\begin{array}{l}\text { C. Balances } \\
\text { customer/stakeholder } \\
\text { demands with the } \\
\text { organization's } \\
\text { objectives }\end{array}$ & $\begin{array}{l}\text { Seeks appropriate guidance } \\
\text { when customers/stakeholders } \\
\text { demand more than has been } \\
\text { agreed upon }\end{array}$ & $\begin{array}{l}\text { Generally balances additional } \\
\text { customer/stakeholder demands } \\
\text { with the needs of the organization } \\
\text { in a manner that is acceptable to } \\
\text { all parties }\end{array}$ & $\begin{array}{l}\text { Expertly balances additional } \\
\text { customer/stakeholder demands with } \\
\text { the needs of the organization in a } \\
\text { manner that meets the major objectives } \\
\text { of all parties }\end{array}$ \\
\hline
\end{tabular}




\section{Strategic/Entrepreneurial Mindset}

\begin{tabular}{|c|c|c|c|}
\hline \multirow[b]{2}{*}{ Behaviors } & \multicolumn{3}{|c|}{ Proficiency Levels } \\
\hline & Level I: Basic & Level II: Intermediate & Level III: Advanced \\
\hline $\begin{array}{l}\text { A. Understands own } \\
\text { organization's } \\
\text { offerings and keeps } \\
\text { current on the } \\
\text { offerings provided by } \\
\text { organizations with } \\
\text { competing or } \\
\text { complementary } \\
\text { services and/or } \\
\text { products }\end{array}$ & $\begin{array}{l}\text { Understands own } \\
\text { organization's offerings, and } \\
\text { maintains a basic } \\
\text { understanding of the } \\
\text { offerings provided by } \\
\text { organizations with competing } \\
\text { or complementary products } \\
\text { and/or services }\end{array}$ & $\begin{array}{l}\text { Maintains a detailed } \\
\text { understanding of the offerings } \\
\text { provided by organizations with } \\
\text { competing or complementary } \\
\text { products and/or services, and } \\
\text { how they compare to own } \\
\text { organization's offerings to } \\
\text { customers or the public }\end{array}$ & $\begin{array}{l}\text { Maintains a thorough understanding of the } \\
\text { offerings provided by organizations with } \\
\text { competing or complementary products } \\
\text { and/or services, as well as the key } \\
\text { differentiators of own organization's } \\
\text { offerings to customers or the public }\end{array}$ \\
\hline $\begin{array}{l}\text { B. Aligns own work with } \\
\text { the organization's } \\
\text { strategy and } \\
\text { objectives }\end{array}$ & $\begin{array}{l}\text { Has a general understanding } \\
\text { of how own role affects the } \\
\text { organization and aligns } \\
\text { efforts with the organization's } \\
\text { stated strategy and objectives }\end{array}$ & $\begin{array}{l}\text { Has a solid understanding of the } \\
\text { impact of own role and aligns } \\
\text { efforts in a way that improves } \\
\text { outcomes for the organization }\end{array}$ & $\begin{array}{l}\text { Thoroughly understands the organization's } \\
\text { broader strategy and plans own work to } \\
\text { maximize impact }\end{array}$ \\
\hline $\begin{array}{l}\text { C. Monitors economic, } \\
\text { market, social, and } \\
\text { societal conditions } \\
\text { and trends }\end{array}$ & $\begin{array}{l}\text { Maintains a general } \\
\text { awareness of economic, } \\
\text { market, social, and societal } \\
\text { conditions and trends }\end{array}$ & $\begin{array}{l}\text { Understands how economic, } \\
\text { market, social, and societal } \\
\text { conditions and trends affect the } \\
\text { organization, customers, or the } \\
\text { public }\end{array}$ & $\begin{array}{l}\text { Closely monitors economic, market, social, } \\
\text { and societal conditions and trends, and } \\
\text { understands the direct and indirect impacts } \\
\text { on the organization, customers, or the } \\
\text { public }\end{array}$ \\
\hline
\end{tabular}


D. Understands and acts upon financial metrics to minimize waste, improve efficiency, and maximize impact

E. Identifies and strategically addresses opportunities to grow offerings or expand into new areas \begin{tabular}{l|l} 
Demonstrates a basic & Understands and uses key
\end{tabular}

understanding of financial

metrics used by the

organization and works to

minimize waste, improve

efficiency, and maximize

impact

Recognizes and investigates options to capitalize on smallscale opportunities that are

directly related to current

work activities

financial metrics to balance costs and benefits to the organization, minimize waste, improve efficiency, and, maximize impact

Identifies small- to mediumscale opportunities to grow offerings or expand into new areas; investigates options and takes steps to capitalize on these opportunities
Understands, leverages, and shares key financial information to improve services or drive competitive advantage for the organization; systematically identifies ways to balance costs and benefits to the organization, as well as minimize waste, improve efficiency, and maximize impact

Seeks and identifies small-to large-scale opportunities to grow offerings or expand into new areas; thoroughly investigates and strategically addresses these opportunities 


\section{Ethics and Social Responsibility}

\begin{tabular}{|c|c|c|c|}
\hline \multirow[b]{2}{*}{ Behaviors } & \multicolumn{3}{|c|}{ Proficiency Levels } \\
\hline & Level I: Basic & Level II: Intermediate & Level III: Advanced \\
\hline $\begin{array}{l}\text { A. Recognizes ethical } \\
\text { challenges and } \\
\text { maintains ethical } \\
\text { standards }\end{array}$ & $\begin{array}{l}\text { Recognizes ethical challenges } \\
\text { and maintains ethical } \\
\text { standards; seeks guidance if } \\
\text { unsure of appropriate } \\
\text { approach }\end{array}$ & $\begin{array}{l}\text { Recognizes ethical challenges } \\
\text { and maintains ethical standards } \\
\text { even when faced with some } \\
\text { external pressure to do } \\
\text { otherwise }\end{array}$ & $\begin{array}{l}\text { Recognizes ethical challenges and } \\
\text { maintains high ethical standards despite } \\
\text { strong external pressures to do otherwise }\end{array}$ \\
\hline $\begin{array}{l}\text { B. Interacts honestly and } \\
\text { transparently with } \\
\text { others }\end{array}$ & Interacts honestly with others & $\begin{array}{l}\text { Interacts honestly and } \\
\text { transparently with others, even } \\
\text { in situations where the truth may } \\
\text { be difficult to communicate or } \\
\text { for others to hear }\end{array}$ & $\begin{array}{l}\text { Acts as a role model for interacting } \\
\text { honestly and transparently with others in } \\
\text { difficult situations despite potential } \\
\text { undesirable consequences }\end{array}$ \\
\hline $\begin{array}{l}\text { C. Demonstrates integrity } \\
\text { and builds trust by } \\
\text { keeping promises and } \\
\text { admitting mistakes }\end{array}$ & $\begin{array}{l}\text { Demonstrates integrity and } \\
\text { builds trust by regularly } \\
\text { keeping promises and } \\
\text { admitting mistakes }\end{array}$ & $\begin{array}{l}\text { Demonstrates integrity and } \\
\text { builds trust by consistently } \\
\text { keeping promises and admitting } \\
\text { mistakes, even when it is } \\
\text { challenging to do so }\end{array}$ & $\begin{array}{l}\text { Acts as a role model for demonstrating } \\
\text { integrity and building trust by always } \\
\text { keeping promises and transparently } \\
\text { admitting mistakes, even when it is very } \\
\text { challenging to do so }\end{array}$ \\
\hline $\begin{array}{l}\text { D. Acts responsibly to } \\
\text { minimize the negative } \\
\text { effects of own choices } \\
\text { on other individuals, } \\
\text { the community, and } \\
\text { the environment }\end{array}$ & $\begin{array}{l}\text { Acts responsibly to ensure own } \\
\text { actions do not harm other } \\
\text { individuals, the community, or } \\
\text { the environment }\end{array}$ & $\begin{array}{l}\text { Balances actions that address } \\
\text { own agenda with sensitivity to } \\
\text { the impact of those actions on } \\
\text { other individuals, the broader } \\
\text { community, and the } \\
\text { environment }\end{array}$ & $\begin{array}{l}\text { Consistently makes socially and } \\
\text { environmentally responsible choices that } \\
\text { respect the rights of other individuals } \\
\text { and the community, and minimize harm } \\
\text { to the environment }\end{array}$ \\
\hline
\end{tabular}


E. Maintains confidentiality of information

F. Makes sustainable social improvements
Recognizes what information

is confidential and/or sensitive

and avoids sharing this

information inappropriately

Participates in activities that

lead to social improvements
Has a solid understanding of

what information is considered confidential or sensitive and handles this information appropriately

Seeks opportunities to introduce initiatives within own area that promote sustainable social improvements
Ensures all team members understand how to appropriately handle sensitive or confidential information and ensures the tools and processes are in place to do so effectively

Leads initiatives that create awareness and promote significant social improvements across the organization 


\section{Global Mindset}

\begin{tabular}{|c|c|c|c|}
\hline \multirow[b]{2}{*}{ Behaviors } & \multicolumn{3}{|c|}{ Proficiency Levels } \\
\hline & Level I: Basic & Level II: Intermediate & Level III: Advanced \\
\hline $\begin{array}{l}\text { A. Demonstrates interest } \\
\text { in, and understanding } \\
\text { of, other geographic } \\
\text { regions, languages, and } \\
\text { cultures }\end{array}$ & $\begin{array}{l}\text { Is open to learning about other } \\
\text { geographic regions, languages, } \\
\text { and cultures }\end{array}$ & $\begin{array}{l}\text { Has interest in other geographic } \\
\text { regions, languages, and cultures, } \\
\text { and views situations with cultural } \\
\text { considerations in mind }\end{array}$ & $\begin{array}{l}\text { Has strong interest in and knowledge } \\
\text { of other geographic regions, } \\
\text { languages, and cultures, and } \\
\text { competently applies cultural } \\
\text { awareness to work }\end{array}$ \\
\hline $\begin{array}{l}\text { B. Recognizes own biases } \\
\text { and balances local and } \\
\text { global perspectives }\end{array}$ & $\begin{array}{l}\text { Is able to recognize how local } \\
\text { ways of thinking may bias own } \\
\text { view and works to understand a } \\
\text { more global perspective }\end{array}$ & $\begin{array}{l}\text { Considers situations from the } \\
\text { perspective of others from } \\
\text { different backgrounds; } \\
\text { recognizes internal biases and } \\
\text { tries to balance local and global } \\
\text { perspectives }\end{array}$ & $\begin{array}{l}\text { Transcends local ideas and ways of } \\
\text { thinking by routinely examining } \\
\text { situations from the perspective of } \\
\text { others from different backgrounds, } \\
\text { correcting for own biases and } \\
\text { balancing local and global } \\
\text { perspectives }\end{array}$ \\
\hline $\begin{array}{l}\text { C. Works effectively with a } \\
\text { global community }\end{array}$ & $\begin{array}{l}\text { Works effectively with } \\
\text { individuals from different } \\
\text { workgroups and locations }\end{array}$ & $\begin{array}{l}\text { Works effectively with } \\
\text { individuals from a wide variety of } \\
\text { organizational areas and global } \\
\text { locations }\end{array}$ & $\begin{array}{l}\text { Seeks opportunities to work globally } \\
\text { by developing partnerships with } \\
\text { individuals from other areas and } \\
\text { locations and looks for opportunities } \\
\text { for collaboration }\end{array}$ \\
\hline $\begin{array}{l}\text { D. Shows an understanding } \\
\text { of other countries' } \\
\text { standards, } \\
\text { certifications, and } \\
\text { processes }\end{array}$ & $\begin{array}{l}\text { Shows awareness that } \\
\text { standards, certifications, and } \\
\text { processes differ by country and } \\
\text { knows where to locate relevant } \\
\text { information }\end{array}$ & $\begin{array}{l}\text { Maintains up-to-date knowledge } \\
\text { of the standards, certifications, } \\
\text { and process requirements of } \\
\text { countries in which own team } \\
\text { frequently performs work }\end{array}$ & $\begin{array}{l}\text { Routinely seeks out information and } \\
\text { updates to maintain an in-depth } \\
\text { understanding of the standards, } \\
\text { certifications, and process } \\
\text { requirements of all countries in which } \\
\text { the organization operates }\end{array}$ \\
\hline
\end{tabular}




\section{Adapting to Change}

\begin{tabular}{|c|c|c|c|}
\hline \multirow[b]{2}{*}{ Behaviors } & \multicolumn{3}{|c|}{ Proficiency Levels } \\
\hline & Level I: Basic & Level II: Intermediate & Level III: Advanced \\
\hline $\begin{array}{l}\text { A. Adjusts work style and } \\
\text { interpersonal } \\
\text { behavior to fit } \\
\text { different situations } \\
\text { and environments }\end{array}$ & $\begin{array}{l}\text { Adjusts work style and } \\
\text { interpersonal behavior when } \\
\text { asked or required to do so, such } \\
\text { as when in a new work } \\
\text { environment }\end{array}$ & $\begin{array}{l}\text { Independently adjusts work style } \\
\text { and interpersonal behavior to fit } \\
\text { most situations and work } \\
\text { environments }\end{array}$ & $\begin{array}{l}\text { Anticipates the need to adjust work } \\
\text { style and adapt behavior to fit nearly } \\
\text { every situation or work environment }\end{array}$ \\
\hline $\begin{array}{l}\text { B. Accepts and integrates } \\
\text { new ideas and } \\
\text { information on their } \\
\text { merits }\end{array}$ & $\begin{array}{l}\text { Considers the merits of new } \\
\text { ideas and information }\end{array}$ & $\begin{array}{l}\text { Accepts and integrates new ideas } \\
\text { and information on their merits, } \\
\text { even if contrary to personal opinion } \\
\text { or previous experiences }\end{array}$ & $\begin{array}{l}\text { Consistently solicits and willingly } \\
\text { accepts and integrates new ideas } \\
\text { and information on their merits, } \\
\text { even if contrary to existing } \\
\text { knowledge or opinion }\end{array}$ \\
\hline $\begin{array}{l}\text { C. Supports and } \\
\text { complies with change } \\
\text { initiatives }\end{array}$ & $\begin{array}{l}\text { Understands change initiatives } \\
\text { and makes efforts to comply }\end{array}$ & $\begin{array}{l}\text { Accepts, supports, and complies } \\
\text { with change initiatives }\end{array}$ & $\begin{array}{l}\text { Champions change initiatives, acting } \\
\text { as a role model for others }\end{array}$ \\
\hline $\begin{array}{l}\text { D. Works effectively } \\
\text { when faced with } \\
\text { ambiguity }\end{array}$ & $\begin{array}{l}\text { Addresses ambiguity by seeking } \\
\text { clarification from others, which } \\
\text { may at times slow down } \\
\text { productivity }\end{array}$ & $\begin{array}{l}\text { When faced with ambiguity, quickly } \\
\text { seeks clarification or makes own } \\
\text { decisions as appropriate while } \\
\text { maintaining productivity }\end{array}$ & $\begin{array}{l}\text { Uses ambiguity as an opportunity to } \\
\text { make a greater impact by setting a } \\
\text { new direction that is aligned with } \\
\text { organizational, government, } \\
\text { community, academic, or customer } \\
\text { needs }\end{array}$ \\
\hline
\end{tabular}




\section{Resilience}

\section{Behaviors}

A. Recognizes own emotions and regulates how they are expressed

B. Maintains focus and productivity under pressure

C. Prioritizes personal well-being and worklife balance and diminishes the negative effects of stress

D. Develops and displays confidence in own capabilities despite obstacles or setbacks
Proficiency Levels

\begin{tabular}{|c|c|c|}
\hline \multicolumn{3}{|c|}{ Proficiency Levels } \\
\hline Level I: Basic & Level II: Intermediate & Level III: Advanced \\
\hline $\begin{array}{l}\text { Recognizes own emotions and } \\
\text { avoids overly emotional displays, } \\
\text { but may exhibit impatience or } \\
\text { frustration when under stress }\end{array}$ & $\begin{array}{l}\text { Recognizes own emotions and } \\
\text { generally projects a positive } \\
\text { attitude; refrains from displaying } \\
\text { emotions in a negative manner }\end{array}$ & $\begin{array}{l}\text { Recognizes own emotions and } \\
\text { consistently projects a positive } \\
\text { attitude and expresses emotions } \\
\text { appropriately, even under the most } \\
\text { stressful circumstances }\end{array}$ \\
\hline $\begin{array}{l}\text { Handles pressure with little loss } \\
\text { of focus or productivity }\end{array}$ & $\begin{array}{l}\text { Maintains focus and productivity } \\
\text { levels when under pressure }\end{array}$ & $\begin{array}{l}\text { Increases focus and productivity } \\
\text { levels when under pressure and is } \\
\text { resilient when faced with work } \\
\text { problems }\end{array}$ \\
\hline $\begin{array}{l}\text { Knows self-care is important and } \\
\text { attempts to manage stress, but } \\
\text { may not be able to prevent work } \\
\text { pressures from impacting } \\
\text { personal well-being at times }\end{array}$ & $\begin{array}{l}\text { Finds appropriate ways to } \\
\text { diminish work pressures and } \\
\text { minimize the negative impact of } \\
\text { stress on personal well-being and } \\
\text { work-life balance }\end{array}$ & $\begin{array}{l}\text { Makes personal well-being and work- } \\
\text { life balance a priority, and } \\
\text { successfully alleviates work pressures } \\
\text { and stress through healthy outlets }\end{array}$ \\
\hline $\begin{array}{l}\text { Develops and displays } \\
\text { confidence in own capabilities } \\
\text { despite minor obstacles or } \\
\text { setbacks }\end{array}$ & $\begin{array}{l}\text { Exhibits confidence in own } \\
\text { capabilities when faced with } \\
\text { ambiguous situations, obstacles, } \\
\text { or setbacks }\end{array}$ & $\begin{array}{l}\text { Consistently exhibits confidence in } \\
\text { own capabilities when faced with } \\
\text { complex, ambiguous situations or } \\
\text { despite substantial setbacks or } \\
\text { significant obstacles }\end{array}$ \\
\hline
\end{tabular}




\section{Leading Others}

\begin{tabular}{|c|c|c|c|}
\hline \multirow[b]{2}{*}{ Behaviors } & \multicolumn{3}{|c|}{ Proficiency Levels } \\
\hline & Level I: Basic & Level II: Intermediate & Level III: Advanced \\
\hline $\begin{array}{l}\text { A. Provides guidance } \\
\text { to others }\end{array}$ & $\begin{array}{l}\text { Provides informal guidance to } \\
\text { team members when } \\
\text { necessary or when requested }\end{array}$ & $\begin{array}{l}\text { Provides guidance to others on tasks or } \\
\text { projects within own area of expertise }\end{array}$ & $\begin{array}{l}\text { Leads informal teams with clear and } \\
\text { accomplished guidance in both own } \\
\text { area and related areas of expertise }\end{array}$ \\
\hline $\begin{array}{l}\text { B. Motivates and } \\
\text { encourages others }\end{array}$ & $\begin{array}{l}\text { Encourages and offers } \\
\text { support to team members } \\
\text { when needed }\end{array}$ & $\begin{array}{l}\text { Works to understand what drives } \\
\text { others and tailors style to attempt to } \\
\text { motivate individual team members }\end{array}$ & $\begin{array}{l}\text { Is a role model for contributing to a } \\
\text { positive work environment where } \\
\text { individual motivations are understood } \\
\text { and team members want to perform at } \\
\text { their best }\end{array}$ \\
\hline $\begin{array}{l}\text { C. Willingly shares } \\
\text { information, } \\
\text { trains, and } \\
\text { mentors others on } \\
\text { areas of expertise }\end{array}$ & $\begin{array}{l}\text { Shares relevant information, } \\
\text { knowledge, and skills with } \\
\text { others }\end{array}$ & $\begin{array}{l}\text { Regularly shares information with } \\
\text { others, and occasionally trains or } \\
\text { mentors team members on areas of } \\
\text { expertise }\end{array}$ & $\begin{array}{l}\text { Proactively engages in opportunities to } \\
\text { share information with others, and } \\
\text { frequently trains or mentors team } \\
\text { members on areas of expertise }\end{array}$ \\
\hline $\begin{array}{l}\text { D. Develops and } \\
\text { communicates a } \\
\text { compelling vision } \\
\text { that is aligned with } \\
\text { the organizational } \\
\text { strategy }\end{array}$ & $\begin{array}{l}\text { Develops a vision for own } \\
\text { work and aligns the vision to } \\
\text { the organization's overall } \\
\text { strategy }\end{array}$ & $\begin{array}{l}\text { Develops a vision aligned with the } \\
\text { organization's strategy for own work } \\
\text { area, and shares this vision with key } \\
\text { stakeholders }\end{array}$ & $\begin{array}{l}\text { Develops a compelling vision aligned } \\
\text { with the organization's strategy for own } \\
\text { unit or program, and explores future } \\
\text { possibilities with appropriate } \\
\text { stakeholders }\end{array}$ \\
\hline
\end{tabular}




\section{Managing the Work of Others}

\begin{tabular}{|c|c|c|c|}
\hline \multirow[b]{2}{*}{ Behaviors } & \multicolumn{3}{|c|}{ Proficiency Levels } \\
\hline & Level I: Basic & Level II: Intermediate & Level III: Advanced \\
\hline $\begin{array}{l}\text { A. Delegates work tasks } \\
\text { to others }\end{array}$ & $\begin{array}{l}\text { Delegates tasks to others to } \\
\text { ensure all work is completed }\end{array}$ & $\begin{array}{l}\text { Delegates work tasks based on } \\
\text { the individual strengths of team } \\
\text { members }\end{array}$ & $\begin{array}{l}\text { Aligns delegated work tasks with the } \\
\text { strengths, interests, and development } \\
\text { needs of team members and the goals of } \\
\text { the work unit }\end{array}$ \\
\hline $\begin{array}{l}\text { B. Monitors } \\
\text { performance of team } \\
\text { members }\end{array}$ & $\begin{array}{l}\text { Monitors performance of team } \\
\text { members to ensure work meets } \\
\text { quality and timeliness } \\
\text { standards }\end{array}$ & $\begin{array}{l}\text { Sets clear performance } \\
\text { expectations for team members } \\
\text { and holds them accountable for } \\
\text { performance }\end{array}$ & $\begin{array}{l}\text { Identifies and tracks key metrics } \\
\text { regarding group and individual } \\
\text { performance as well as achievement of } \\
\text { team goals }\end{array}$ \\
\hline $\begin{array}{l}\text { C. Provides others with } \\
\text { clear direction and } \\
\text { expectations }\end{array}$ & $\begin{array}{l}\text { Provides direction and helps } \\
\text { others to understand } \\
\text { expectations }\end{array}$ & $\begin{array}{l}\text { Communicates priorities and } \\
\text { provides guidance to others, } \\
\text { helping them to understand } \\
\text { expectations }\end{array}$ & $\begin{array}{l}\text { Consistently communicates clear } \\
\text { priorities and objectives to help others to } \\
\text { understand expectations, meet } \\
\text { challenging goals, and maximize } \\
\text { accountability and productivity }\end{array}$ \\
\hline $\begin{array}{l}\text { D. Provides feedback } \\
\text { and coaching to } \\
\text { others }\end{array}$ & $\begin{array}{l}\text { Provides performance feedback } \\
\text { to others }\end{array}$ & $\begin{array}{l}\text { Provides timely feedback on } \\
\text { performance and progress in } \\
\text { light of expectations and goals, } \\
\text { and coaches others to improve } \\
\text { performance }\end{array}$ & $\begin{array}{l}\text { Identifies needs for employee } \\
\text { development and provides ongoing, } \\
\text { constructive feedback and coaching to } \\
\text { others, highlighting performance } \\
\text { strengths and areas for improvement }\end{array}$ \\
\hline
\end{tabular}




\section{2o. Leveraging Technology}

\begin{tabular}{|c|c|c|c|}
\hline \multirow[b]{2}{*}{ Behaviors } & \multicolumn{3}{|c|}{ Proficiency Levels } \\
\hline & Level I: Basic & Level II: Intermediate & Level III: Advanced \\
\hline $\begin{array}{l}\text { A. Applies } \\
\text { technology tools } \\
\text { and techniques } \\
\text { to gather and } \\
\text { store } \\
\text { information }\end{array}$ & $\begin{array}{l}\text { Applies basic technology } \\
\text { tools and techniques to } \\
\text { uncover new information, } \\
\text { and effectively uses existing } \\
\text { systems to retrieve and store } \\
\text { data }\end{array}$ & $\begin{array}{l}\text { Applies advanced technology tools } \\
\text { and techniques as well as multiple } \\
\text { sources to uncover new } \\
\text { information; effectively uses a } \\
\text { broad array of resources to retrieve } \\
\text { and store data }\end{array}$ & $\begin{array}{l}\text { Applies advanced technology tools and } \\
\text { comprehensive sources and techniques to } \\
\text { search for new information and retrieve and } \\
\text { store data }\end{array}$ \\
\hline $\begin{array}{l}\text { B. Uses technology } \\
\text { and visual aids } \\
\text { to facilitate and } \\
\text { enhance } \\
\text { communications }\end{array}$ & $\begin{array}{l}\text { Effectively uses common } \\
\text { communication technologies } \\
\text { and prepares basic visual aids } \\
\text { to supplement written or } \\
\text { verbal explanations }\end{array}$ & $\begin{array}{l}\text { Effectively uses new or advanced } \\
\text { communication technologies; uses } \\
\text { appropriate communication } \\
\text { medium for the audience and } \\
\text { situation, and prepares visual aids } \\
\text { that clearly communicate } \\
\text { information without additional } \\
\text { explanation }\end{array}$ & $\begin{array}{l}\text { Effectively uses all available communication } \\
\text { technologies, including advanced or novel } \\
\text { applications, to enable new modes of sharing } \\
\text { information and ideas; consistently chooses } \\
\text { appropriate communication medium for the } \\
\text { audience and situation, and prepares visual } \\
\text { aids that clearly and succinctly communicate } \\
\text { complex information without additional } \\
\text { explanation }\end{array}$ \\
\hline $\begin{array}{l}\text { C. Leverages } \\
\text { standard } \\
\text { technology and } \\
\text { applications to } \\
\text { complete work }\end{array}$ & $\begin{array}{l}\text { Has a basic knowledge of } \\
\text { standard technology and } \\
\text { applications, and uses these } \\
\text { tools to perform work with } \\
\text { minimal guidance }\end{array}$ & $\begin{array}{l}\text { Has a broad knowledge of standard } \\
\text { technology and applications and } \\
\text { requires no guidance in using these } \\
\text { tools }\end{array}$ & $\begin{array}{l}\text { Has a comprehensive knowledge of standard } \\
\text { technology and applications; is seen by others } \\
\text { as an expert in their application and identifies } \\
\text { new applications for enhancing own and } \\
\text { others' productivity }\end{array}$ \\
\hline
\end{tabular}

Continued 
D. Applies professionspecific or other specialized applications to complete work

E. Stays up-to-date on technological changes
Has a basic knowledge of relevant profession-specific or specialized applications and can use these tools to perform work with occasional guidance

Stays current on relevant technological changes that are needed on the job
Has a thorough knowledge of most relevant profession-specific or specialized applications and can use these tools to perform work with minimal guidance

\section{Seeks out new and improved} technologies to apply to present and future work
Has a comprehensive knowledge of all relevant profession-specific or specialized applications; requires no guidance in using these tools and is seen by others as an expert in their application

Anticipates future needs and identifies emerging tools, technologies, and methodologies that may assist with meeting work goals; develops or introduces new information technology applications to the organization

Laureate Education Workplace Skills Competency Framework by Laureate Education, Inc. is licensed under a Creative Commons AttributionNonCommercial 4.0 International License.

The Higher Learning Research Communications (HLRC), is a peer-reviewed, online, interdisciplinary journal indexed in Scopus, ERIC, JGATE and Directory of Open Access Journals (DOAJ). It is an open access journal with an international focus published by Walden University, USA. Its aim is to disseminate both high quality research and teaching best practices in tertiary education across cultures and disciplines. $H L R C$ connects the ways research and best practice contribute to the public good and impact the communities that educators serve. HLRC articles include peer-reviewed research reports, research briefs, comprehensive literature reviews, and books reviews. 